J. Linguistics 51 (2015), 383-423. C Cambridge University Press 2014

This is an Open Access article, distributed under the terms of the Creative Commons Attribution licence (http://creativecommons.org/licenses/by/4.0/), which permits unrestricted re-use, distribution, and reproduction in any medium, provided the original work is properly cited.

doi:10.1017/S0022226714000486 First published online 9 December 2014

\title{
Syncope, syllabic consonant formation, and the distribution of stressed vowels in English ${ }^{1}$
}

\author{
KRISZTINA POLGÁRDI \\ Research Institute for Linguistics, Hungarian Academy of Sciences
}

(Received 4 January 2013; revised 6 May 2014)

Post-tonic synope in English (Received Pronunciation) optionally deletes a schwa between a stressed and an unstressed vowel (gén(e)ral), but it cannot apply if the vowel following the schwa is stressed (gén*(e)ràte), or if no vowel follows (hápp*(e)n). Syncope is thus triggered by a metrical lapse of unstressed vowels. In addition, short stressed vowels cannot occur in an open syllable in English (Stress-to-Weight), except when preceding a single consonant and a vowel. Hammond (1997a) analyses such seemingly open stressed syllables in words like gén(e)ral as closed by a virtual geminate. I argue that post-tonic syncope can be understood as another means of satisfying the Stress-to-Weight requirement, closing the stressed syllable in a different way, at the same time avoiding a metrical lapse. In addition, surprisingly, English post-tonic syncope is sensitive to the quality of the flanking consonants: the consonant following the alternating vowel must be a sonorant which is more sonorous than the consonant preceding it $\left(\right.$ dél$^{*}(i)$ cate, cól*(o)ny). These are the same conditions as those applying to syllabic consonant formation, which can be regarded as a stage preceding syncope, explaining the melodic restrictions. I analyse the interplay of different forces in Stratal Optimality Theory, employing Government Phonological representations.

\section{INTRODUCTION}

In this paper, I analyse post-tonic syncope in English (Received Pronunciation, RP) in a Loose CV framework, a recent version of Government Phonology (see Lowenstamm 1996; Polgárdi 1998, 2002). Post-tonic syncope optionally deletes a schwa between a stressed and an unstressed vowel, as in gén(e)ral. If a stressed vowel follows, as in gén*(e)ràte, or if there is no following vowel, as in hápp* $(e) n$, then syncope does not apply. Syncope is thus triggered by a sequence of unstressed vowels in English.

Examining the distribution of English short stressed vowels, we find that they cannot stand before a vowel or word-finally. That is, they cannot occur in syllable-final position, except when they are followed by a single consonant and a vowel, as in city. Hammond (1997a), analysing this pattern, required stressed syllables to be heavy in English (Stress-to-Weight), and proposed to

[1] I would like to thank Katalin Balogné Bérces, Tobias Scheer, Péter Szigetvári, three anonymous $J L$ referees, and participants of the 19th Manchester Phonology Meeting for valued comments on previous versions of this paper. 
close the seemingly open stressed syllable in words like city or géneral by a virtual geminate. In this paper, I argue that syncope can be understood as another means of satisfying the Stress-to-Weight requirement, by closing the stressed syllable in a different way, at the same time avoiding a metrical lapse of unstressed vowels.

A curious feature of English post-tonic syncope is that it is sensitive to the quality of the flanking consonants: the consonant following the alternating vowel must be a sonorant which is more sonorous than the consonant preceding the schwa (i.e. no syncope is possible in words like dél*(i)cate or cól*(o)ny). These are the same conditions as those applying to syllabic consonant formation, which can be regarded as a stage preceding syncope, which explains the melodic restrictions.

In this paper, I employ Government Phonological representations, combined with constraint interaction in the framework of Stratal Optimality Theory (Bermúdez-Otero 2012). Optionality of both syncope and syllabic consonant formation is captured by the theory of Partially Ordered Grammars (Anttila 2007). In addition to facilitating an account of all the intricacies of syncope in English, this combination has also provided motivation to identify syllabic consonant formation as a stem-level process (pace Borowsky 1993). Finally, this analysis forms a natural basis of an extension to a corpus-based account of the lexical variation exhibited by syncope based on relative usage frequency.

The paper is structured as follows. To provide sufficient background for the following discussion, in Section 2, I present the data on the distribution of short and long stressed vowels, and Hammond's (1997a) (partial) analysis. Section 3 contains the Loose CV analysis of stressed vowels in English. ${ }^{2}$ Section 4 presents the data on syncope, an initial analysis in terms of proper government, and the problems which this approach faces. In Section 5, I turn to syllabic consonant formation, which enables a solution of those problems. Section 6 integrates the findings in an analysis involving constraint interaction in terms of Stratal Optimality Theory. Section 7 summarises the results.

\section{Stress-to-Weight in English}

Let us first examine the patterning of stressed vowels in English (Received Pronunciation). (The data presented below are based on Jones 1966; Chomsky \& Halle 1968; Gimson 1980; Wells 1982, 1990; Kreidler 1989; Harris 1994; Rubach 1996; Hammond 1999; Nádasdy 2006; Burzio 2007.) The table in (1) shows the distribution of short and long stressed vowels (the latter including diphthongs) in different syllabic positions. I only consider monomorphemic forms here. The symbol $\$$ stands for syllable boundary and the symbol \# stands

[2] Sections 2 and 3 provide a summary of Polgárdi (2012). 
for word boundary. (The complete system of full vowels, including the tense-lax distinction, can be found in Appendix.)

Distribution of stressed vowels in syllable structure

\begin{tabular}{|c|c|c|c|}
\hline & (i) Short & (ii) Long \\
\hline \multirow[t]{3}{*}{ Internal } & (a)_\$CV & 'siti 'city' & 'mi:tə 'meter' \\
\hline & (b) _ $\mathrm{CSCV}$ & 'vęktə 'vector' & - \\
\hline & (c)_\$V & * & 'rü:n 'ruin' \\
\hline \multirow[t]{3}{*}{ Final } & (d)_\# & $*$ & brau 'brow' \\
\hline & (e)_C\# & hük 'hook' & hog:k 'hawk' \\
\hline & (f)_CC\# & gيllp 'gulp' & - \\
\hline
\end{tabular}

Columns (i) and (ii) show that the distribution of short and long vowels is almost complementary in English. Short vowels do not occur before a vowel, see (1i.c), and word-finally, see (1i.d), that is, they cannot stand at the end of a syllable, except as in (1i.a). Long vowels, in contrast, cannot occur in a closed syllable, as is shown in (1ii.b) and (1ii.f), except in (1ii.e). ${ }^{3}$ These generalisations are summarised in (2).

\section{(2) Generalisations}

(a) Short vowels must be followed by a tautosyllabic consonant (but: (1i.a)).

(b) Long vowels cannot be followed by a tautosyllabic consonant (but: (1ii.e)).

Note that the restrictions in (1b) and (1f) do not apply to coronal clusters, and clusters involving [s] (indicated by '- ', instead of '*'), and examples like shoulder ['Jəuldə], easter ['iistə], paint [pernt], and ask [a:sk] exist (although $[\mathrm{s}]+$ non-coronal clusters like the last one only occur after long vowels in accents like RP that lengthened the historically short vowel in this environment). I will not deal with these cases further here (see e.g. Borowsky 1989, Harris 1994, Hall 2001 for possible treatments). ${ }^{4}$

The pattern in (1i) can be accounted for by requiring stressed syllables to be heavy in English (Stress-to-Weight), as proposed by Hammond (1997a). In his analysis, a nonreduced syllable in English must be minimally bimoraic

[3] Long lax vowels are also ruled out prevocalically. This is the effect of a general ban on prevocalic lax vowels (whether short or long, stressed or unstressed). I will not discuss it further here.

[4] Sequences of more than two consonants following short vowels, where the last two consonants cannot form a branching onset, as in empty, antler or mulct, exist in English, but they are rare, and the so-called intrusive obstruent in forms like empty is optionally absent. An exhaustive list is provided by Borowsky (1989). I will not discuss them further here. 
(or bipositional). Long vowels and diphthongs satisfy this requirement underlyingly, while in a closed syllable containing a short vowel, the second mora is provided by the coda consonant (Weight-by-Position). (1i.c, d), like *['rum] and *[bræ], are then excluded because a short vowel in an open syllable is light, i.e. monomoraic.

To account for examples like ['sti] in (1i.a), Hammond (1997a) assumes that the stressed syllable in such cases is in fact closed, albeit by a virtual consonant, namely, a covert geminate, providing the second mora required. Hammond follows Borowsky, Itô \& Mester's (1984) proposal that cases of apparent ambisyllabicity must be treated as gemination (see also Van der Hulst 1984, 1985 for the same idea). Such geminates are virtual because their phonological length does not correspond to phonetic length, but it is still recoverable from their environment (i.e. they behave as if they were long). As virtual geminates are predictable, they cannot be contrastive.

Apart from the distribution of stressed vowels, independent evidence for virtual geminates in English is provided by expletive infixation, as discussed by Hammond \& Dupoux (1996). As shown in (3), the expletives fuckin' and bloody can be placed between two feet within a word (in certain dialects).

(3) Expletive infixation (Hammond \& Dupoux 1996: 290)
(a) fantastic [,fæn'tæstrk] fan-fuckin'-tastic
(b) Tennessee [,tenว'si: $]$ Tenne - fuckin' - see
(c) typhoon [,tai'fu:n] ty-fuckin'-phoon
(d) raccoon [,ræ'ku:n] *

The expletive can appear after a consonant, as in (3a), a schwa, as in (3b), or a long vowel, as in (3c), but it cannot occur after a short vowel, as (3d) indicates. If the stressed short vowel is followed by a virtual geminate, then the lack of expletive insertion can be explained by Geminate Integrity because the virtual geminate straddles the foot boundary in examples like (3d). (In addition, Hammond \& Dupoux (1996) also cite psycholinguistic evidence for this view on syllabification of intervocalic consonants and consonant sequences.)

The restriction in (1ii.b, f) above, that is, that superheavy rhymes, involving long vowels in closed syllables, are ruled out as well in English (i.e. examples like *['vi:kta] and *[gu:lp] are ill-formed) is analysed by Borowsky (1989). To account for this, she poses an upper limit on rhymes (at Level 1), restricting them to contain maximally two positions (or moras). In addition, she assumes that final consonants are extrasyllabic. Therefore certain types of 'superheavy rhymes', like those in (1ii.e) and (1i.f), are well-formed in English, but only word-finally (viz. [ho:k] (VV\$C) and [g^lp] (VC\$C)), because now such rhymes are also bipositional (which, of course, will not help examples like *[gu:lp], still being tripositional).

If we want to combine the insights of Hammond and Borowsky in a unified analysis, then stressed rhymes in English need to be restricted to EXACTLY TWO 
positions (for an analysis of Dutch rhymes along the same lines, see Van der Hulst 1984, 1985; Kager \& Zonneveld 1986). This means that after stress assignment, a word-final consonant must be incorporated into the rhyme when it directly follows a stressed short vowel, as in [huk] in (1i.e), to satisfy the bipositional requirement. Final consonants of 'superheavy rhymes', in contrast, must be extrasyllabic, to be able to state the complementary distribution between short and long stressed vowels, and to explain the pattern in (1i-ii). However, using extrasyllabicity in this way is stipulatory, as is requiring rhymes to contain exactly two positions (and not for example exactly three, exactly four, etc.).

In Polgárdi (2012), I analyse this pattern in a recent version of Government Phonology, which provides several advantages.

\section{A Loose CV analysis with trochaic proper government}

Let me begin with the basic ingredients of the analysis, the underlying assumptions that I adopt. I follow Lowenstamm's (1996) Strict CV approach in the idea that syllable structure consists of strictly alternating $\mathrm{C}$ and $\mathrm{V}$ positions. As a consequence, the representation of closed syllables, geminate consonants and long vowels involves an empty position, as shown by the hypothetical forms in (4).

(4) Strict CV (Lowenstamm 1996)

(a) Closed syllable (b) Geminate consonant (c) Long vowel
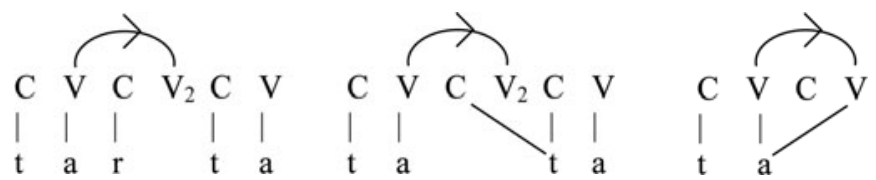

Geminates and long vowels are built up of two CV units. In a geminate the consonantal melody straddles an empty $\mathrm{V}$ position, while in a long vowel the vocalic melody straddles an empty $\mathrm{C}$.

Following Rowicka (1999a, b), I employ trochaic (left-to-right) proper government instead of the more usual right-to-left type, ${ }^{5}$ as defined in (5).

(5) Trochaic (left-to-right) proper government (Rowicka 1999a, b)

A nuclear position $A$ properly governs a nuclear position $B$ iff

(a) $A$ governs $B$ (adjacent on its projection) from left to right

(b) $A$ is not properly governed.

[5] Iambic proper government was proposed by Kaye (1990) and Kaye et al. (1990), and it has been employed by most proponents of Government Phonology. Advocates of trochaic proper government include Gibb (1992) and Yoshida (1999). 
Government is a binary, asymmetric relation between skeletal positions. Proper government, indicated by a curved arrow in (4) and in subsequent diagrams, is a special form of government, which works in conjunction with the Empty Category Principle, given in (6).

\section{(6) Empty Category Principle (ECP) (Kaye, Lowenstamm \& Vergnaud 1990: 219) \\ A position may be uninterpreted phonetically if it is properly governed.}

As a result, an empty $\mathrm{V}$ position may remain silent if it is properly governed, as shown by $\mathrm{V}_{2}$ in $(4 \mathrm{a}-\mathrm{b})$ above. However, if an empty $\mathrm{V}$ position is not properly governed, then it must surface as the default vowel (illustrated by the schwa following the long vowel in the example of charlatan [' $\int a$ :lətən] in (11b) below).

Finally, I use a so-called Loose CV skeleton instead of the Strict CV one (as argued for in Polgárdi 1998, 2002). These two approaches are not radically different: word-medially they are the same, they only differ (potentially) at the edges. More precisely, Loose CV dispenses with domain-final empty nuclei that are always inaudible. This means that words do not need to end in a $\mathrm{V}$ position: $\mathrm{C}$-final words are allowed (just like $\mathrm{V}$-initial words, when there is no phonetic consonant initially). However, word-medially a strict alternation of $\mathrm{C}$ and $\mathrm{V}$ positions is still required.

Domain-final empty nuclei present some serious problems, as discussed in Polgárdi (1998). One of the problems is illustrated in (7), where the noun-forming suffix -er is added to the verb listen, resulting in the form listener. In a Strict CV approach, the root ends in the empty $\mathrm{V}_{3}$, while the suffix starts with the empty $\mathrm{C}_{4}$. This empty sequence is then customarily deleted, indicated by angle brackets, referred to as the operation of Reduction by Gussmann \& Kaye (1993).

\section{(7) Strict CV: Reduction}

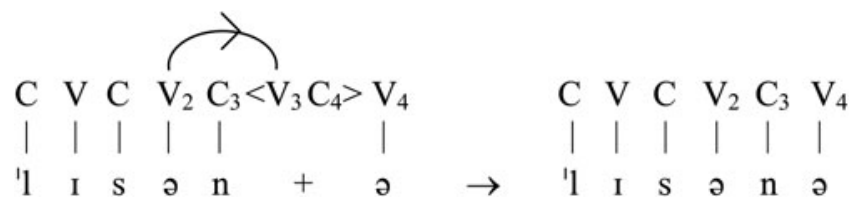

This is, however, problematic because it violates the Projection Principle, given in (8), by also removing the proper governing relation between $V_{2}$ and $V_{3}$.

(8) Projection Principle (Kaye et al. 1990: 221)

Governing relations are defined at the level of lexical representation and remain constant throughout a phonological derivation.

In a Loose CV approach, as shown in (9), no reduction is necessary, as a consonant-final root and a vowel-initial suffix can simply be concatenated. As a result, no governing relationship has been deleted in this analysis. 
(9)

Loose CV: No reduction

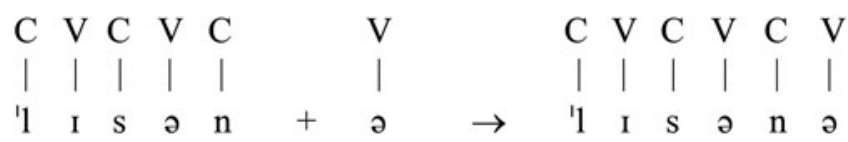

In Polgárdi (2012), I propose to analyse the bipositional requirement on stressed rhymes (Stress-to-Weight) by demanding that the stressed position in English properly govern an empty nucleus to its right. A heavy rhyme corresponds to two $\mathrm{CV}$ units in the $\mathrm{CV}$ approach, bound by trochaic proper government, as shown in $(4 \mathrm{a}-\mathrm{c})$ above. ${ }^{6}$ As proper government is a binary, nontransitive relation, the requirement automatically ensures that stressed rhymes will be both minimally and maximally bipositional. ${ }^{7}$ Extra motivation for this requirement may be found in the melodic representation of vowels. Since short vowels in English are lax, and lax vowels are melodically represented as headless while tense vowels as headed in Government Phonology (e.g. Cobb 1997), this requirement ensures that all stressed rhymes are headed in some sense. Although lax vowels cannot be headed by themselves, they can satisfy the requirement by heading a proper governing relation with a following empty nucleus. Short vowels in seemingly open rhymes are followed by a virtual geminate to satisfy the requirement, similarly to Hammond's (1997a) proposal.

Let us now see how the data in (1) can be analysed in this approach. The representation of stressed vowels (underlined) preceding a single intervocalic consonant, i.e. in a word-internal 'open syllable', is shown in (10).

- $\$ \mathrm{CV}(=(1 \mathrm{a}))$

(a) Short: virtual geminate

(b) Long
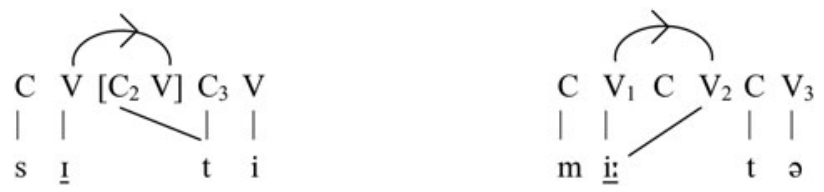

The representation of a long vowel involves two CV units, as seen in (10b). According to Rowicka (1999a, b), the relationship between the two halves of a

[6] Note that with iambic proper government, it is not easy to identify the relevant units.

[7] Note that the implication only works in one direction, i.e. if there is stress, then there is also a proper governing domain, but not in the opposite direction, and therefore unstressed 'closed syllables' exist in English. Although heavy syllables typically attract stress in this language, there are exceptions word-internally (e.g. character ['kærəktə]), and more word-finally as a result of final syllable extrametricality in nouns (e.g. agent ['erdzant]). Unstressed heavy syllables also occur in word-initial pretonic position (mostly comprising a Latinate prefix, as in conform [kən'fə:m]), and in two-sided clash configurations (e.g. guarantee [gærən'ti:]). Thus, even though the Weight-to-Stress principle is active as well, it can be violated in certain situations, unlike Stress-to-Weight, which is in focus in this paper. 
long vowel is one of proper government. Since the $C$ position between $V_{1}$ and $V_{2}$ is unfilled, this governing relationship is manifested by spreading the melodic content of $V_{1}$ into $V_{2}$. The ECP permits properly governed positions to remain uninterpreted, but it does not demand that they do so. Therefore, the realisation of $\mathrm{V}_{2}$ in (10b) does not contradict the ECP. (In those cases where the intervening C position is filled, there is of course no possibility, or need, for spreading, as in vector in (11) below, for example.) In this analysis, the $\mathrm{V}_{2}$ position is properly governed by $V_{1}$ and not by $V_{3}$, satisfying in this way the requirement on stressed positions in English to properly govern an empty nucleus to their right.

The stressed short vowel in (10a) is also required to properly govern an empty nucleus to its right, therefore it is followed by an extra CV unit, indicated by square brackets in (10a) and in representations below. I assume, following Bermúdez-Otero (2012), that stress assignment in English is represented by lexical redundancy rules so as to account for its limited productivity and lexical exceptions. Thus, lexical entries are fully prosodified stem-level output structures, also already containing the extra $\mathrm{CV}$ unit standing for tonic lengthening in forms like (10a). ${ }^{8}$ As proposed by Larsen (1998), a totally empty CV unit cannot remain completely silent. ${ }^{9}$ If its $\mathrm{V}$ position is not properly governed, then it must be interpreted as the default vowel, according to the ECP. If the V position of the empty $\mathrm{CV}$ unit is properly governed, then it is required that at least one of its positions be eventually filled via spreading (Larsen 1998). This more specific requirement thus overrides the ECP.

The extra CV unit in (10a) is properly governed, therefore spreading ensues. In principle, either the neighbouring vowel or the consonant could lengthen, but lengthening the vowel would neutralise the contrast between (10a) and (10b). As consonant length is not contrastive in English, spreading the melody of the following consonant into $\mathrm{C}_{2}$ avoids such neutralisation. However, phonetically there are no long consonants in standard English, ${ }^{10}$ so the resulting geminate is merely virtual. (For earlier use of this device in Strict CV phonology, see for example Lowenstamm 1991, 1996; Larsen 1994; Ségéral \& Scheer 2001; Barillot \& Ségéral 2005.) By contrast, virtual gemination of the vowel would not be possible because a virtual long vowel in (10a) would occur in the same

[8] See Larsen (1998) and Ségéral \& Scheer (2008) for proposals of inserting an extra CV unit after the stressed V position in languages with tonic lengthening, and Chierchia (1986) for a solution in terms of a branching rhyme requirement. I discuss Larsen's (1998) and Ségéral \& Scheer's (2008) analysis and how they differ from the present one in more detail in Polgárdi (2012).

[9] This restriction does not apply to the initial empty CV unit proposed by Lowenstamm (1999), which replaces the boundary symbol \#, traditionally used to identify the beginning of the word. This site normally remains silent. In this paper, employing trochaic proper government, however, I cannot adhere to the idea of the initial site.

[10] This does not hold for fake geminates, as the [n:] in un\#natural, the two halves of which are separated by a word-level boundary. However, their phonological representation is quite different from that of the true (albeit virtual) geminates discussed here, as the melody of the former is lodged distinctively in both $\mathrm{C}$ positions separately and does not result from spreading to an empty position. 
context as the phonetically long vowel in (10b), and there would be no way to tell why one can remain phonetically short while the other one cannot. The length of the virtual geminate, on the other hand, is predictable from its environment.

Finally, to preserve the insight that in both (10a) and (10b) the spreading melody is distinctively located only in the head position, $\mathrm{C}_{3}$ and $\mathrm{V}_{1}$, respectively, and it is phonologically unspecified in the dependent position, I employ Harris' (1994: 167) notion of spreading as interpretation. The line connecting the melody to the dependent position then simply indicates the domain over which that melody should be phonetically interpreted. (Of course, as it happens, in the virtual geminate the melody is NOT interpreted phonetically in $\mathrm{C}_{2}$. Nevertheless, the domain is phonologically demarcated.) In this analysis, virtual geminates in English are present underlyingly in the same way as long vowels are, and their distribution is captured by the lexical redundancy rules responsible for stress. Thus, (10a-b) show that the superficially similar surface forms in (1i.a) and (1ii.a) in fact have different representations. ${ }^{11}$

The diagrams in (11) show stressed vowels in the word-internal 'closed syllable' context.

$$
\text { - } \operatorname{C\$ CV~}(=(1 b))
$$

(a) Short

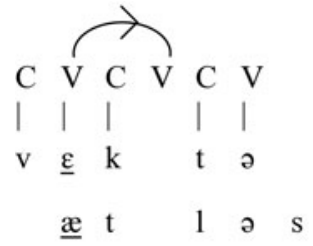

(b)

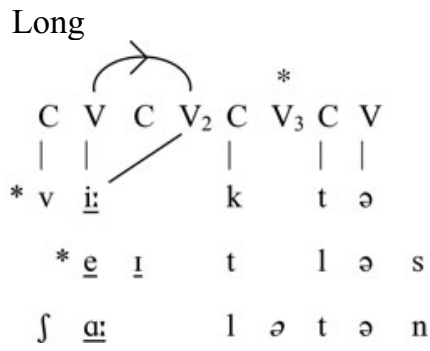

A stressed short vowel can occur here because it can properly govern the empty nucleus to its right, as is shown in (11a). A long vowel, however, cannot occur in this position, see $(11 \mathrm{~b})$, because the governed $V_{2}$ position cannot properly govern $\mathrm{V}_{3}$. An ungoverned position such as $\mathrm{V}_{3}$, however, cannot remain silent. It is for this reason that a long vowel cannot be followed by an inaudible nucleus. Of course, if the ungoverned $\mathrm{V}_{3}$ is filled by the default vowel, schwa, as in the example of charlatan [' Ja:lətən], then the preceding long vowel is well-formed.

The contrast in (11) in fact provides an additional argument for a CV representation: the restriction concerning short vs. long vowels shown in (11a-b) applies not only in the case of coda-onset clusters, but also before so-called 'bogus

[11] Stressed vowels preceding a word-internal 'branching onset', like macro ['mækrəu] and micro ['markrəu], have a representation entirely parallel to those in (10a-b), as the empty nucleus inside the internal cluster $k r$ does not need to be properly governed, because it is trapped inside a closed domain of consonantal interaction, called infrasegmental government, which licenses it to remain silent (Scheer 1999). 
clusters' (e.g. atlas ['ætləs], but *['ertləs], ${ }^{12}$ again well-formed with a pronounced schwa inside the cluster, as in odalisque ['วudəlisk]), where the consonants cannot form either a coda-onset cluster, or a branching onset in any version of Government Phonology, therefore they must be separated by an empty nucleus (e.g. Kaye et al. 1990). ${ }^{13}$ In a standard Government Phonology analysis, the restriction cannot be formulated in a uniform way: long vowels are ruled out in a closed syllable and preceding an empty nucleus. In the CV approach both contexts involve a following empty nucleus, requiring proper government.

The representations in (12) illustrate the situation of hiatus, that is, the context before a vowel.

$$
\text { _ } \$ \mathrm{~V}(=(1 \mathrm{c}))
$$

(a) Short: CV unit cannot remain empty

(b) Long
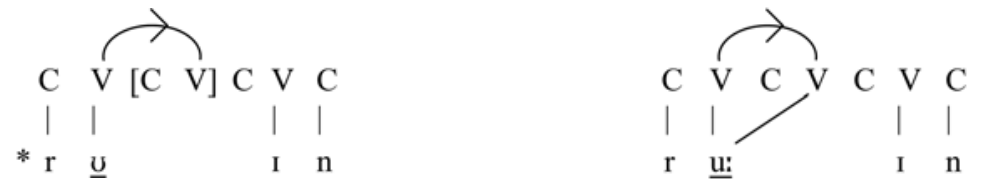

A stressed short vowel cannot occur in this position because it needs to properly govern, but the required extra $\mathrm{CV}$ unit, indicated by square brackets in (12a), cannot be filled, as there is no consonantal melody on the right to spread there. The vocalic melody of [I] cannot spread either because long vowels are left-headed, and therefore in this case an illicit representation would arise. Since properly governed CV units cannot remain completely empty, such a representation is illformed. A long vowel, in contrast, can occur in this position without further provisions, as seen in (12b). The representation of stressed vowels in absolute word-final position in (1d) above (*[bræ] vs. brow [brav]) is completely parallel to those in $(12 \mathrm{a}-\mathrm{b})$, therefore I do not provide them separately.

The examples in (13) illustrate the context before a single word-final consonant.

$$
\text { _ C\# (= (1e)) }
$$

(a) Short

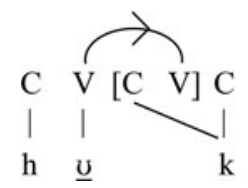

(b) Long

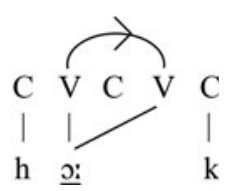

[12] There are a handful of exceptions, like evening ['i:vnı] and maudlin ['mə:dlin], containing a long vowel before a bogus cluster.

[13] In standard Government Phonology (Kaye et al. 1990) consonant clusters come in three types. In complex onsets and coda-onset clusters, the consonants are considered adjacent, as evidenced by phonotactic constraints holding between them: the first type is (roughly) restricted to non-homorganic obstruent-liquid sequences, the second to clusters of falling sonority. Any other type of consonant cluster is considered 'bogus', that is, separated by an inaudible nucleus. Of course, in a Strict/Loose CV framework, all clusters enclose an empty nucleus. 
These representations are entirely parallel to the ones given in (10) above, with the exception of the lack of a final vowel. In Strict CV, even this difference would be missing because both forms would end in an empty $\mathrm{V}$ position. This, however, would result in ill-formed representations because these empty nuclei would be ungoverned, and therefore could not remain silent, as shown in (11b) above. This could be remedied by reintroducing the parameter of domain-final licensing (which has been made superfluous by switching to trochaic proper government) just for these cases. The problem with this solution is that words like finish would then have two possible analyses, one where the final empty nucleus is governed by the preceding pronounced vowel, and another where it is licensed parametrically. In Loose CV, these problems can be avoided because here words do not need to end in a $\mathrm{V}$ position. ${ }^{14}$

Finally, let us examine the context before two word-final consonants in (14).

_ CC\# (= (1f))

(a) Short

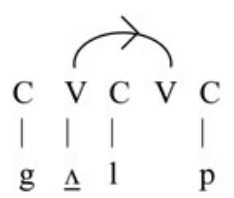

(b) Long

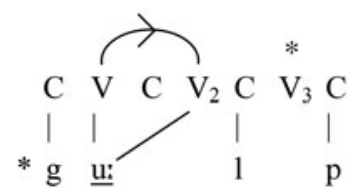

Again, these representations are parallel to those in $(11 \mathrm{a}-\mathrm{b})$, and a stressed short vowel can occur in this environment, as is shown in (14a), because it can properly govern the empty nucleus inside the final cluster, whereas a long vowel is illicit in this position, see $(14 b)$, because the ungoverned $V_{3}$ cannot remain silent. Note also that it no longer needs to be stipulated that 'superheavy rhymes' such as (13b) and (14a) can only occur word-finally because the 'bachelor' Cs (i.e. Cs without a following $\mathrm{V}$ ) involved in such rhymes are restricted to the edges.

One further question arises in relation to (14a), namely, whether bogus clusters are also allowed to follow short vowels word-finally, just as they were allowed word-internally in (11a). The answer is that they are not, but this is in fact part of a larger pattern, extending to word-final branching onsets, which are also absent. That is, the generalisation is that rising sonority at the end of the word is

[14] The question might arise here whether in words like hook [huk] the virtual geminate is necessary, instead of having a CVCv representation with a final empty nucleus being properly governed by the stressed $\mathrm{V}$ position. In fact, in Dutch, where virtual geminates are present before stress assignment, exactly that representation has been proposed for this type of final sequences by Polgárdi (2008), to account for the fact that they behave as heavy, and not as superheavy, with respect to stress, and are therefore skipped (in contrast to internal virtual geminates which attract stress, similarly to other closed syllables). In English, however, virtual geminates are based on stress, and therefore this kind of evidence is unavailable. Support for the structure in (13a) can be provided by the parallel treatment of word-internal cases in (10), and by the gemination facts in Welsh English, discussed below. 
interpreted as a syllabic peak in English, i.e. as a pronounced V position ${ }^{15}$ - as all such words can either be pronounced with a schwa followed by a non-syllabic sonorant (as in settle ['setəl], muffle ['m^fəl]), or with a syllabic sonorant without a preceding schwa (['setl], ['mıfl]). Syllabic consonants in English behave like unstressed vowels (as discussed below, in Section 5). This is also shown by the fact that they can be preceded by a long vowel in this position (as in beetle ['bi:tal]/['bi:tl]), which is not true of word-internal bogus clusters. The requirement that the $\mathrm{V}$ position inside a word-final rising sonority cluster must be pronounced overrides potential proper government of an empty nucleus in this position, shown in $(15 \mathrm{a}-\mathrm{b})$ for the two possibilities.

Word-final rising sonority clusters: Pronounced $V$ position

(a) settle ['sctəl]

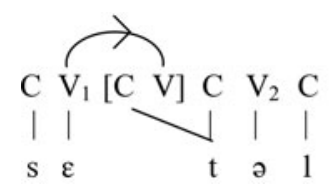

(b) settle ['setl]

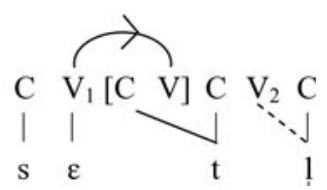

Schwa, as in (15a), is the default vowel. A syllabic consonant, as in (15b), will be analysed below as branching on a preceding $\mathrm{V}$ position in English (following Szigetvári 1999 and Scheer 2004), accounting for its alternation with schwa in $(15 \mathrm{a}-\mathrm{b})$. As a syllabic consonant acts like any other unstressed vowel, virtual geminates are necessary in $(15 \mathrm{a}-\mathrm{b})$ to satisfy the requirement of proper government. Finally, coda-onset sequences as in (14a) behave differently because in them sonority is falling.

In summary, stressed short and long vowels are in complementary distribution in English. At this point, let me summarise the advantages of the present analysis over previous approaches. As opposed to the bipositional rhyme analysis (following Hammond 1997a and Borowsky 1989), where stressed 'rhymes' were required to contain EXACTLY TWO positions, in the present analysis the restriction is no longer arbitrary: a stressed position must properly govern an empty nucleus to be a head in some sense. Defining properties of proper government include that it is binary and non-transitive (arrived at on the basis of independent evidence, e.g. vowel $\sim$ zero alternation in various languages). Therefore, in this analysis, variation is restricted to two possibilities: either a language requires stressed vowels to properly govern or there is no such requirement. In a bipositional rhyme approach, in contrast, there is no reason why rhymes should be restricted

[15] The only exceptions monomorphemically involve stop + [s] clusters, as in lax [læks]. These have been analysed by assigning [s] to an appendix (see the discussion in Harris (1994: 81-82), for example). Across a morpheme boundary, in addition to [s], as in lacks [læks], [z], as in hugs [h^gz], and [ $\theta]$, as in eighth [ert $\theta]$, also appear in this context. Note, however, that all monoconsonantal suffixes in English involve a coronal obstruent, and we have already seen in (1) that these can violate phonotactic restrictions respected by other consonants. Therefore, I will not deal with them further here. 
to exactly two positions, instead of any other imaginable number. As no other numbers seem to be supported empirically, such an analysis overgenerates. ${ }^{16}$ In addition, a CV analysis can unify the representations of coda-onset clusters and bogus clusters, both of which can provide a following context for short vowels. Another advantage is that there is no need (or even possibility) for extrasyllabicity, and all final consonants are treated in a uniform manner, that is, as a 'bachelor' C. In the extrasyllabic account, only final consonants of 'superheavy rhymes' are analysed as extrasyllabic, whereas consonants following short stressed vowels belong to the rhyme. Therefore, a final 'bachelor' $\mathrm{C}$ is not equivalent to extrasyllabicity, neither is it invented for the sake of 'superheavy rhymes'.

Furthermore, an analysis employing virtual geminates is supported by accents like Welsh English, where the distribution of short and long stressed vowels in syllable structure is identical to that shown in (1) (although differences in melodic identity can be found), but where virtual geminates in fact become audible. Different sources do not agree exactly about the context of lengthening. Thomas (1984: 185) only mentions that 'single consonants in medial position following a short stressed vowel are phonetically long', as in (16a).

\section{Welsh English}

(a) _ $\$ C V(=(1 \mathrm{a} . \mathrm{i}))$



(b)

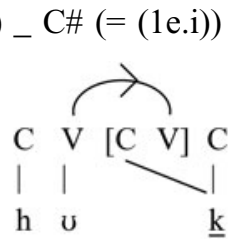

[huki:]

However, Connolly (1981) also reports lengthening in the word-final context, as in (16b). In his description, lengthening also applies after [i: u:] and the diphthongs, when these are fully shortened before a fortis consonant, and to certain, not precisely specified, types of clusters (the latter of which I cannot account for here).

\section{Post-tonic syncope}

With this background, we can now turn to the phenomenon of syncope. Data on syncope in this paper partly come from Guile (1972), Zwicky (1972), Algeo (1974), Hooper (1978), Harris $(1994,2011)$ and Szigetvári $(2002,2007)$. In addition, I have used the electronic database at http://seas3.elte.hu/epd, based on Hornby, Cowie \& Windsor Lewis (1974), and the database of Lindsey \& Szigetvári (2013) at http://seas3.elte.hu/cube, where frequency counts are also supplied, to search for additional examples. I have checked all examples cited here in Wells' (1990) Longman Pronunciation Dictionary.

[16] Thanks to Tobias Scheer for suggesting this argument. 
Post-tonic syncope in English optionally deletes a schwa between a stressed and an unstressed vowel. Here I will not discuss pre-tonic cases of syncope, occurring in examples like potato [p(ə)'tertəu] or support [s(ə)'pə:t], because they involve a separate process, applying only in fast, casual speech. The type of syncope examined here, although optional, applies in non-fast, non-casual speech.

In the pairs of examples in (17), the first item can exhibit syncope, while the second one cannot.

\section{Syncope (optional)}

$\mathrm{C}_{1}$ ə $\mathrm{C}_{2} \rightarrow \mathrm{C}_{1} \mathrm{C}_{2} /$ stressed $\mathrm{V}$ unstressed V

(a) $\mathrm{C}$ unstressed $\mathrm{V}$

\begin{tabular}{|c|c|c|c|}
\hline séparate $_{\mathrm{A}}$ & ['seprət] & séparàte $_{\mathrm{V}}$ & $*$ ['sepreit $]$ \\
\hline jávelin & ['dzævlın] & fáculty & *['fæklti] \\
\hline háppening & ['hæpnin] & háppen\# & *['hæpn] \\
\hline définite & ['defnət] & délicate & $*\left[{ }^{\prime} \mathrm{d} \varepsilon \mathrm{lk} \partial \mathrm{t}\right]$ \\
\hline mémory & 'memri] & cólony & $*$ ['kplni] \\
\hline
\end{tabular}

Post-tonic syncope is only possible in English if the schwa is followed by a single consonant and an unstressed vowel, as in sép $(a)$ rate $_{A}$, jáv(e)lin, or hápp(e)ning in (17a). ${ }^{17}$ If the vowel after the following consonant is stressed $\left(\right.$ sép $^{*}(a)$ ràte $\left.{ }_{V}\right)$, or if the schwa is followed by a cluster $\left(f a c^{*}(u)\right.$ lty), or by a word-final consonant (hápp*(e)n\#), then syncope is not allowed. In addition, syncope is sensitive to the quality of the flanking consonants. The consonant following the alternating vowel can only be a liquid or a nasal, as in déf(i)nite, and it cannot be an obstruent, as in dél*(i)cate, in (17b). Furthermore, the consonant following the schwa must be more sonorous than the consonant preceding it, ${ }^{18}$ therefore syncope is possible in mém $(o) r y$, but it is ruled out in cól $^{*}(o) n y$, in $(17 \mathrm{c})$.

Finally, apart from being optional, another important characteristic of this process is that it is also lexically variable: that is, in the same prosodic and melodic context, a schwa may alternate with zero in one word (e.g. sím(i) lar ['simələ]/ ['simlə]), but not in another (e.g. anómalous [ə'npmələs]/*[ว'nomləs]), while in yet a further example the form without the schwa may be lexicalised (e.g. fám(i)ly ['fæmli]) (and there is dialectal and inter-speaker variation in which word behaves in which way). The main factor that this difference is based on involves relative usage frequency of lexical items. Fidelholtz (1975) was the first to note that more frequent words are more prone to reduction processes. He examined vowel reduction in initial closed syllables in English. Hooper (1976) observed the same generalisation for post-tonic syncope. The process of $t / d$-deletion shows the same pattern, as discussed by Coetzee (2009) and

[17] As far as the stressed vowel is concerned, it can bear primary stress, as in the examples in (17), or secondary stress, as in nùm(e)rológical [,nju:mrə'lodżkl].

[18] Authors usually assume the following sonority/strength hierarchy: vowels - glides $-[\mathrm{r}]-[1]-$ nasals - fricatives - stops (see e.g. Zwicky 1972, Hooper 1978). 
Coetzee \& Pater (2011) (who also mention several further examples from other languages).

The generalisations in (17) are based on intuitions of the authors cited, which are confirmed to varying degrees by corpus studies (on American English). Dalby's (1986) study, analysing television broadcast speech, and slow and fast reading, shows a difference between pre- and post-tonic syncope: deletion rate in post-stress word-medial position is much higher than in other positions of the word in broadcast speech, and especially in slow reading, whereas deletion rate in pre-stress position increases radically in fast reading. On the other hand, the sonority restrictions presented in (17) are not confirmed by Dalby's results. Patterson, LoCasto \& Connine (2003) find an even greater difference in deletion rate between the post-stress and pre-stress environments than Dalby, analysing conversations between strangers over the phone, and between friends in face-to-face interaction. However, they fail to confirm the influence of speech rate on the frequency of deletion. In addition, they identify two groups of words within the post-stress type which show a marked difference in deletion rate. One factor inhibiting deletion is identified as a following stressed syllable. Patterson et al. (2003) do not investigate the melodic identity of consonants flanking the syncope site, but almost all the examples they examine conform to the restrictions discussed in (17). Davidson (2006), investigating normal and fast reading, argues for analysing pre-tonic syncope in English as a result of gestural overlap, instead of deletion, on the basis of evidence showing phonetic traces of presence of a vowel on the neighbouring consonants. In addition, the influence of speech rate on pre-tonic syncope has been confirmed for some speakers, but not for others in this study. Finally, Balogné Bérces (2011) discusses lexicalisation of syncope and finds that all such cases involve post-tonic syncope, observing the sonority restrictions in (17). ${ }^{19}$ As can be seen, these studies sometimes show contradictory results, but as each generalisation in (17) is supported by at least some of them, in my opinion it is justified to attempt an analysis of that pattern.

Post-tonic syncope is thus triggered by a sequence of unstressed vowels, and it does not apply if there is only a single unstressed vowel, either in a word-final syllable (hápp $*(e) n \#)$ or followed by a stressed vowel, where the degree of stress is immaterial (the final stress in sép ${ }^{*}(a)$ ràte ${ }_{V}$ has been analysed both as secondary and as tertiary in the literature, but syncope is also blocked preceding a primary stress, as in $\mathrm{fat}^{*}(a)$ listic). Therefore, the driving force behind syncope is the presence of a metrical lapse, and I propose that the decision about which unstressed vowel should delete is determined by the requirement of proper government introduced in Section 3 above. That is, we can explain why it is normally the posttonic vowel which deletes (and not the following one), as this provides another

[19] The only exceptions I am aware of are méd(i)cine ['medsən] and vég(e)table ['veḑtəbəl]. 
means of satisfying the governing duty of stressed vowels, as shown in (18). ${ }^{20} \mathrm{In}$ the following representations, $\mathrm{V}$ positions inside virtual geminates are not numbered, to ease comparison between syncopated and unsyncopated forms.

\section{Two ways of satisfying the requirement of proper government}

(a) Virtual geminate: metrical lapse $(=(10 a))$

(b) Syncope (= (11a))
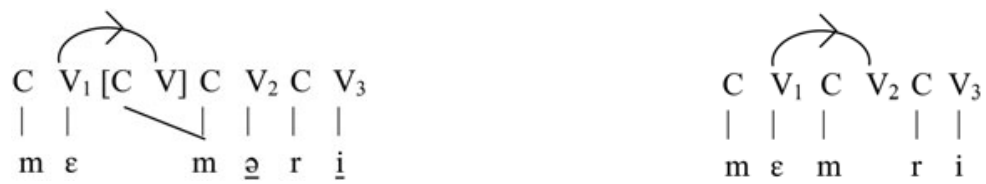

The representation in (18a) satisfies the requirement by the presence of the virtual geminate, while at the same time containing a sequence of two unstressed vowels, $\mathrm{V}_{2}$ and $\mathrm{V}_{3}$, that is, a metrical lapse. In (18b), as a result of syncope, the metrical lapse is avoided, and there is no need for the virtual geminate either. ${ }^{21}$ If a stressed vowel follows the schwa, there is no metrical lapse to trigger syncope, and therefore it does not occur.

In the Government Phonological literature, syncope is generally accounted for by iambic, right-to-left, proper government, like the one between $V_{2}$ and $V_{3}$ in (19a) (e.g. Harris 1994, Szigetvári 1999).

Iambic proper government

(a) Within a stress domain

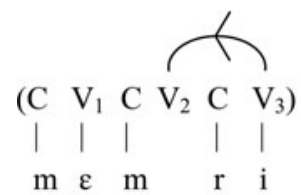

(b) Across stress domains

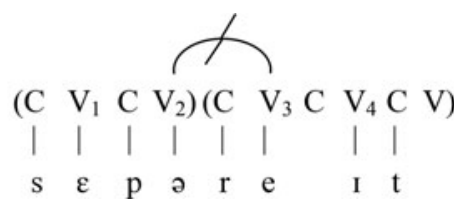

Then, however, it is unclear why only an unstressed vowel can properly govern, and what the role of the preceding stressed vowel is. As for the first question, Szigetvári (1999: 79) proposes the Antipenetration Constraint, which prohibits government from penetrating a stress domain. In (19a) $V_{2}$ and $V_{3}$ are in the same stress domain (shown by the parentheses on the CV tier). But in (19b) $\mathrm{V}_{3}$, being stressed, starts a new stress domain and is therefore not allowed to govern $\mathrm{V}_{2}$, and syncope is ruled out. However, this analysis cannot work because there are many examples like chàrismátic or magnólia in English, with a

[20] As we will see below, in words like innovat(o)ry ['məvətrI] syncope occurs in a syllable that is not immediately post-tonic. Such examples are not included in most descriptions of syncope probably because in General American the vowel that syncopates in RP is actually strong: ['məvətว:rr]. Their behaviour will fall out of the interplay of some additional forces.

[21] As an anonymous $J L$ referee observes, this analysis predicts that in Welsh English [m] should only be long in (18a), while in (18b) it should surface as short. Unfortunately, this prediction cannot be tested because there is no post-tonic syncope in Welsh English (Thomas 1984: 183). 
bogus cluster preceding a stressed vowel, where the empty nucleus enclosed by the underlined consonants must be governed to be able to remain silent. Trochaic proper government solves these problems, by integrating syncope into the patterning of stressed vowels in English. (For the exact formulation of how syncope is triggered by a metrical lapse, see Section 6 below.)

As we have seen in (18), syncope occurs before a single consonant and an unstressed vowel. The representations in (20) show the two other contexts illustrated in (17a) where syncope does not occur.

\section{Right-hand context}

(a) $\quad \mathrm{CC} f a c^{*}(u)$ lty $(=(11 \mathrm{~b}))$

(b)

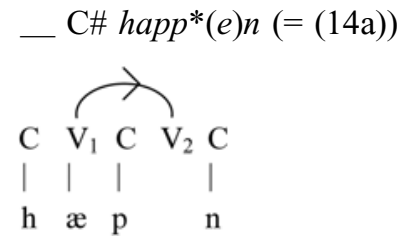

The structure in (20a) is similar to the one in (11b) above: if the $V_{2}$ position is governed, it cannot properly govern $\mathrm{V}_{3}$, which, in turn, cannot remain silent, and the representation is ill-formed. This is why syncope does not apply preceding a consonant cluster. The structure in (20b) is parallel to the one in (14a), and yet it is ruled out as a result of syncope. The reason is twofold: on the one hand, the situation is similar to the one where a stressed vowel follows: if the schwa precedes a word-final consonant, there is no metrical lapse to trigger syncope. On the other hand, in word-final rising sonority clusters, the $\mathrm{V}_{2}$ position must be pronounced in English, as has been discussed with respect to (14a) above, i.e. it cannot be properly governed.

There is another interesting property of syncope in English, which is unexpected in a CV account involving either type of proper government, namely, the schwa can also be deleted after a consonant cluster or a long vowel, or combinations thereof, as shown in (21).

\section{(21) Left-hand context}
(a) CC cómp(a)ny
víct(o)ry
ádm(i)ral
(b) VV ív(o)ry
árs(e)nal
(c) VVCC dáng(e)rous

The clusters preceding the syncope site are mostly coda-onset clusters, as the first two examples in (21a), and sometimes bogus clusters, as the third example, but there are no examples with a complex onset in this position. This gap can be explained by the representation of complex onsets, involving an infrasegmental 
governing domain, which has to be licensed by a following pronounced $\mathrm{V}$ position according to Scheer (1999).

The question is how syncope is possible in words like (21). The problem is illustrated in (22).

Lack of a proper governor

(a) Cluster

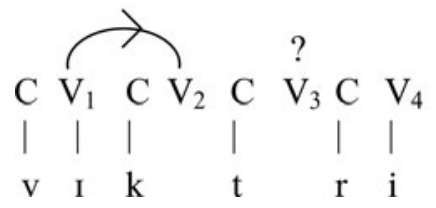

(b) Long vowel

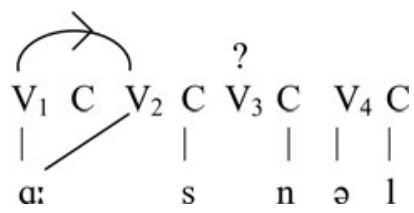

In both representations, it is unclear what triggers syncope, as $V_{2}$ is itself properly governed and therefore cannot serve as a proper governor for $V_{3}$. For iambic proper government, the representations are equally problematic because in that case it is $\mathrm{V}_{2}$ that lacks a proper governor.

Another problem faced by an analysis in terms of proper government of either direction concerns the melodic restrictions on the consonants flanking the syncope site, shown in $(17 \mathrm{~b}-\mathrm{c})$. As proper government operates on the nuclear projection, it should be blind to the quality of the surrounding consonants. In fact, this is one of the reasons why proper government has been such a successful tool in accounting for vowel $\sim$ zero alternation: it captures the cross-linguistic sonority-blindness of the process. Vowel $\sim$ zero alternations analysed in terms of proper government include e.g. Tangale (Nikiema 1989), Moroccan Arabic (Kaye 1990), French (Charette 1991), Hungarian (Törkenczy 1992), Polish (Gussmann \& Kaye 1993) and Czech (Scheer 2004).

The sonority restrictions found in English are also left unexplained by analyses involving deletion of melody as well as position, accompanied by resyllabification. Hooper (1978), for example, states that syncope in English creates syllable-initial clusters, i.e. branching onsets. However, many of these clusters (like [vl pn fn $\mathrm{mr}$ ] in (17)) do not occur syllable-initially in English lexically, but are rather analysed as coda-onset clusters in an approach like Hooper's, and as bogus clusters in terms of standard Government Phonology. In addition, some other clusters which are considered syllable-initial by Hooper, i.e. [s]+ stop clusters, cannot be produced by syncope (as in góss*(i)ping), together with all other falling sonority clusters (as in dél*(i)cate in $(\overline{17} \mathrm{~b})$ ). Thus, possible resulting clusters do not form a straightforward class in this approach either.

\section{Syllabic CONSONANT FORMATion}

We might gain better understanding of these issues by examining the phenomenon of syllabic consonant formation (SCF) in English (Szigetvári 2002), illustrated in (23). Comparing (23) to (17) above, it can be observed that the 
restrictions on syllabic consonant formation are very similar to, although less stringent than, those on syncope. In both cases, a post-tonic schwa is optionally deleted between two consonants, the second of which is a liquid or a nasal, if the second consonant is more sonorous than the first one (23a).

(23) Syllabic consonant formation (post-tonic)

$\mathrm{C}_{1}$ ə $\mathrm{C}_{2} \rightarrow \mathrm{C}_{1} \mathrm{C}_{2}$ (optional), $\mathrm{C}_{2}=$ sonorant
(a) $\mathrm{C}_{1}<\mathrm{C}_{2}$
cámel
['kæml]
(b) $\ldots$ \#
cólumn
*['kplm]
(c) $-\mathrm{C}$
háppen\# ['hæpn]
(d) _ unstressed V séparate $_{\mathrm{A}}$ ['seprot $]$
fáculty ['fæklti]
séparàte $_{\mathrm{V}} \quad *\left[{ }^{\prime}\right.$ sepr, ert $]$
(e) _ syllabic $\mathrm{C}$ nátional_ ['næfnl]
(f) $\mathrm{C}_{1}=\mathrm{r} \quad$ cáramel ['kærml]
flànnelétte [,flænl' $\varepsilon t]$
(g) + ex. (21)

$\begin{array}{ll}\text { bárrel } & \text { ['bærl] } \\ \text { pátron } & \text { ['pertrn] } \\ \text { cárd(i)nal } & \text { ['ka:dnl] }\end{array}$

In the case of SCF, the second consonant takes over the syllabic role of the deleted vowel and, indeed, it behaves like a(n unstressed) vowel. It can occur at the end of the word, as in (23b), before another consonant, as in (23c), before an unstressed vowel, as in (23d), or before another syllabic consonant, see (23e). ${ }^{22}$ The case of a following stressed vowel is somewhat less clear, as SCF is ruled out in séparàte $_{\mathrm{V}}$, but it is possible in flànnelétte (23d), according to Wells (1990). As will be shown below, a specific type of morpheme boundary needs to separate the sonorant from the stressed vowel for SCF to take place (i.e. it does not apply pre-tonically within monomorphemic forms). The examples in (23f) show that $[\mathrm{r}]$ can contradict the sonority requirement and can be followed by a syllabic consonant which is less sonorous. ${ }^{23}$ Finally, (23g) illustrates that syllabic consonants can also follow long vowels and consonant clusters, and all the examples in (21) could be added here (which can then proceed further to complete syncope). That syllabic consonants behave like vowels is also shown by the fact that complex onsets can be found in this environment, as shown by the example of pátron. In addition, syllabic consonants can follow non-lexical bogus clusters, created by syncope, as in cárd(i)nal.

[22] [r] cannot occur in the contexts of $(23 b-c)$ in RP because it is deleted in word-final and preconsonantal position, i.e. when it is not followed by a filled $\mathrm{V}$ position.

[23] [wəl] sequences are also exceptional in this sense and can result in a syllabic [1] (as in equal ['i:kwl]). However, this is not a general property of glides, or even of [w] itself, as SCF is not possible in words like sequence, calculus or onion. 
Comparing the application of syncope and SCF, we can conclude that SCF can be regarded as a stage preceding syncope (Harris 1994, Szigetvári 2002). That is, for each syncopated form, there is also a form with a syllabic consonant, and as a result there is ternary free variation, as in ['dzenərəl]/['dzenrəl]/['dzenrəl]. The reverse, however, does not hold, i.e. a form with a syllabic consonant may have no corresponding syncopated form, in which case there is free variation only between two forms, as in ['plenəri]/['plenri] $/ *$ ['plenri].

This chronology explains the strange melodic restrictions on syncope, which are not so strange in the context of SCF. The consonant following the syncope site must be a sonorant because only sonorants can become syllabic in English. This restriction applies to syllabic consonants in many other languages as well (Bell 1978). In addition, if SCF in English aims at preserving rising sonority between a consonant and a following vowel, then the second consonant must be more sonorous than the first one, to be able to replace the vowel in this role. I have found no explanation for why [r] can form an exception to this condition. But forms like caramel ['kærml] and irony ['ar(ว)rni] cannot proceed to syncope (i.e. *['kærml], *['ar(ə)rni]) because a short lax or (broken) tense vowel $+[\mathrm{r}]+$ non-syllabic consonant sequence is ill-formed in English. ${ }^{24,25}$ Therefore, in syncope the sonority requirement is strictly observed, and $[\mathrm{r}]$ is no exception to it.

In linear phonology, syllabic consonants were represented as [+consonantal, +syllabic] segments (e.g. Chomsky \& Halle 1968: 354; Bell 1978), which has mostly corresponded to a consonantal melody associated to a nuclear position in non-linear phonology (e.g. Clements 1990, Blevins 1995). This approach, however, is problematic because it involves resyllabification during the creation of the syllabic consonant, and in languages like English, also at the next step, during syncope, when the consonant becomes non-syllabic again. Resyllabification is a powerful device, and it should be avoided if simpler solutions are also available.

Government-based approaches, therefore, represent syllabic consonants by spreading the melody distinctively located in a $\mathrm{C}$ position into a neighbouring $\mathrm{V}$ position, thereby capturing the fact that syllabic consonants have both consonantal and vocalic properties. In the case of syncope (proper government) in English, spreading does not go through, but the structure again remains intact. In the literature, proposals have been made for both a left-branching (e.g. Szigetvári 1999: 117ff.; Toft 2002; Scheer 2004) and a right-branching structure (e.g. Rowicka 1999b: 258ff.; Rennison 1999; Blaho 2004) for syllabic consonants. Here I follow the left-branching view, as shown in (24), since the

[24] In RP, a solution could be to delete the [r] as well, but this does not happen, which seems to be a language-specific choice. In Tangale, for example, if syncope creates an ill-formed cluster, it is reduced further by deletion of the offending consonant (Charette 1991: 108).

[25] Historical short lax vowels in this context have undergone the no longer active process of broadening (as in barn [barn], accompanied by [r]-deletion and compensatory lengthening in RP [ba:n]), while tense vowels are ruled out before consonant clusters in general (with about a dozen counter examples with an rC-cluster, like beard). 
syllabic consonant takes the place of a preceding schwa and behaves like an unstressed vowel in that position (see (15) above). Some further arguments are provided below.

Syllabic consonants: Left-branching (= (10a))
(a) _ C ['fæklti]
(b) _ \# ['hæpn]
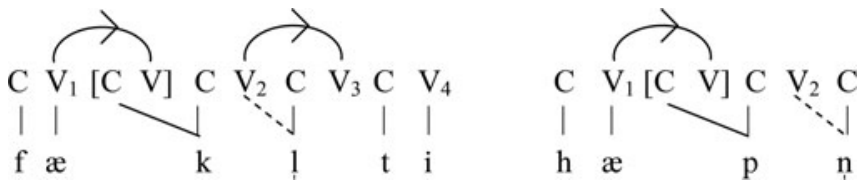

As a syllabic consonant acts like any other pronounced vowel, virtual geminates are necessary in $(24 a-b)$ to satisfy the requirement of proper government. Unlike (20), the representations in (24) are well-formed because $V_{3}$ is properly governed by $V_{2}$ in (24a) and because $V_{2}$ is pronounced inside the word-final rising sonority cluster in $(24 b)$.

The representations in (25) show that a syllabic consonant forms a metrical lapse with a following schwa in the same way as any other unstressed vowel does, and this lapse is then resolved by syncope in the same way as it was in (18) above.

(a) Syllabic consonant $(=(10 a))$

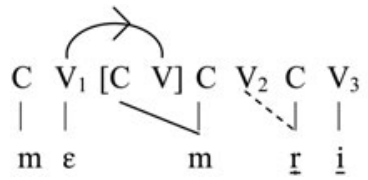

(b) Syncope (=(11a))

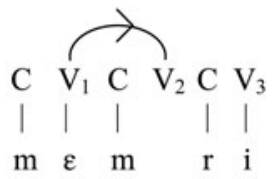

In contrast to (22), the representations in (26) are well-formed because $V_{3}$ is pronounced, and therefore it does not need a proper governor.

(26) No proper governor needed for $V_{3}$

(a) Cluster

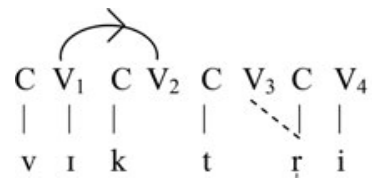

(b) Long vowel

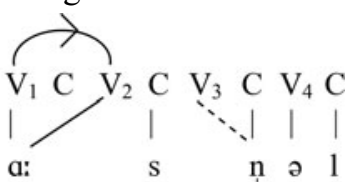

The question now is why these forms can proceed further and syncopate, when this is impossible in a form like (24a). While I cannot answer this question in a satisfying way at the moment, a difference can be observed between the structures in (26) and the one in (24a): in (24a) the potential target of syncope, $V_{2}$, has a governing duty to fulfil, which is not the case in (26). Whatever makes it possible for $V_{3}$ to remain silent in (26) is overruled by the governing duty of $V_{2}$ in (24a). I leave this question open for further research. 
Let us briefly return to the question why a right-branching structure is not appropriate for syllabic consonants in English. This structure has been proposed to be universally valid by Blaho (2004) and Scheer (2009), on the basis of Slavic evidence. Their main arguments, however, are all refuted by English. In Czech and Slovak a syllabic consonant cannot be followed by a pronounced vowel within the same morpheme, whereas in English it can (e.g. memory ['memri]), in which case the syllabic consonant would have no place to spread to. Syllabic consonants can be followed by consonant clusters in Czech (['vlhki:] 'humid'), and Slovak (['krtgma] 'inn'), producing a sequence of silent empty nuclei, unless the syllabic consonant branches to the right; but English has no such forms (except for a handful of examples with a following branching onset, like concentrate, or if there is an intervening word-level boundary, as in elegant\#ly). In contrast, syllabic consonants in English can be freely PRECEDED by consonant clusters, as shown in (23g) and analysed in (26). Vowel $\sim$ zero alternation can occur after a syllabic consonant in Czech (['blbsts $\sim$ 'blbtsc] 'idiot (NOM, SG) (GEN, SG)'), again producing a following cluster, whereas this normally cannot happen in English (again there are a handful of exceptions, like invent $(o) r y$, all with the suffix -ory/-ery/-ary, but we have seen in (21) that syncope in English can unexpectedly apply across a cluster also after a stressed vowel). Again, vowel zero alternation can occur BEFORE a syllabic consonant in English, see (23g) above. Therefore, it seems to be a parameter, rather than a universal, in which direction a syllabic consonant spreads, and in English ample evidence points in the left direction. Note that in an analysis where syllabic consonants solely occupy the nucleus, this typological difference is mysterious and it cannot be captured, providing further support for a branching representation.

Finally, according to Toft (2002), Southern British English syllabic [n] should be represented by a left-branching structure, whereas syllabic [1] should be connected exclusively to a nucleus, to express the fact that $[\mathrm{n}]$ is more restricted in its distribution and that it has longer duration. Then, however, it will be difficult to express their unitary behaviour with respect to syncope, whose representation in the case of [1] will also be substantially complicated. In addition, the distributional differences are not absolute, but gradient, whereas the representational differences proposed by Toft are categorical, which leaves no room for the variation actually observed.

I also disagree with the idea that a branching representation of syllabic consonants necessarily corresponds to extra length phonetically. Blaho (2004) argues, on the basis of a contrast between short and long syllabic consonants in Slovak, that length is expressed by linking some melody to two positions of the same type (either both Cs, or both Vs). Accordingly, branching involving a $\mathrm{C}$ position and a $\mathrm{V}$ position does not correspond to phonetic length. Instead, it expresses the fact that syllabic consonants exhibit both consonantal and vocalic characteristics. In addition, Price (1980) shows that apart from duration, amplitude and voice onset time also provide phonetic cues to distinguish syllabic from non-syllabic consonants in English. 
Furthermore, the branching representation of syllabic consonants is not interpreted as a sequence of a syllabic consonant followed by a non-syllabic one of the same melodic composition either, that is as *['hæpnn] for happen in (24b), for example. As such sequences do not occur at all in English (except across a word-level boundary, as in barren\#ness), there is no contrast between [nn] and [n]. Therefore, in English a syllabic consonant is simply the interpretation of a branching structure like the one in $(24 b)$.

\section{Deriving Syncope}

Now we are ready to formalise the analysis of syncope more precisely. On the basis of the evidence presented in Section 5, I propose that syncope in English needs to be restricted to proper government of (the $\mathrm{V}$ position of) a syllabic consonant. SCF is a separate process, which applies first (optionally), and syncope is then optional on the output of SCF. In that way, the sonority restrictions need not be taken into account by proper government: they are already satisfied by its input.

In my view, syncope in English results from a 'conspiracy' of different forces: one aiming at avoiding lapses, another requiring stressed positions to properly govern, and a third striving against rising sonority within word-final consonant clusters. Such conspiracies are best expressed by Optimality Theoretic constraint interaction (Prince \& Smolensky 1993, McCarthy \& Prince 1995). However, in standard Optimality Theory (OT), evaluation is parallel, ruling out intermediate representations, and ordering between processes. Therefore, here I argue for a Stratal OT analysis of these phenomena (e.g. Kiparsky 2000, Bermúdez-Otero 2012). This approach recognises three levels: the stem, the word, and the phrase level.

For syllabic consonant formation to be able to precede syncope, the two processes must belong to different levels. And, in fact, it can be shown that SCF applies at the stem level in English, while syncope is a word-level process. If we examine word-level suffixes starting with a sonorant consonant, we find that in those starting with a nasal, -ness and -ment, the initial consonant never becomes syllabic after a schwa, see (27a). Also, it always forms a fake geminate with a preceding identical consonant, indicated by doubling of the symbol in (27b) (where the stem-final consonant might become syllabic if it follows a schwa, the option marked by curly brackets), and a preceding [i] cannot weaken to schwa, see $(27 \mathrm{c})$.

(27) Syllabic consonant formation: Nasal-initial word-level suffixes
(a) ə _ wilderness ['wildənəs] sacrament ['sækrəmənt]
(b) $\mathrm{C}_{\mathrm{i}}$ _ openness ['วup $\{\partial \mathrm{n} / \mathrm{n}\}$ nəs] embalmment [Im'ba:mmənt]
(c) i _ happiness ['hæpinəs] merriment ['merimənt]

Word-level suffixes starting with [1], -less and -ly, are not as clear-cut (and no suffix starts with [r]). After a schwa, -less mostly retains a non-syllabic [1] but 
with some stems, as in odourless, it undergoes SCF, while -ly can almost always undergo SCF and there are only a few examples like slenderly, with only nonsyllabic [1], see (28a).

(28) Syllabic consonant formation: [l]-initial word-level suffixes

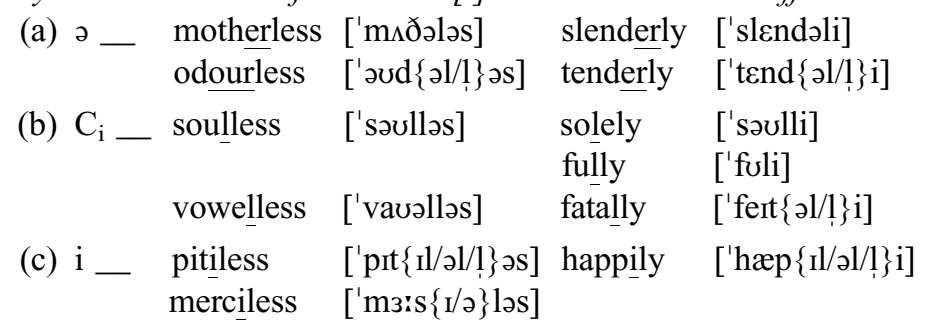

With an identical stem-final consonant, the [1] of -less always forms a fake geminate (whether after a stressed or an unstressed vowel), as in (28b). Following a stressed vowel, the [1] of -ly mostly forms a fake geminate, which in some words can optionally degeminate (e.g. dully), and in a few words, like fully, only short [1] occurs. After an unstressed vowel, degemination is obligatory, and SCF is optional. Finally, a stem-final [i] weakens to [I] or [ə] before both suffixes, and the [1] of -less sometimes undergoes SCF, whereas the [1] of -ly can always do so, see (28c). The behaviour of -less and especially of -ly is thus ambiguous: with certain stems they act like a stem-level suffix while with others they show word-level behaviour. Similar problems have been identified with respect to other languages (e.g. Hungarian, Rebrus 2000), and as far as I know no satisfactory solution has been found. On the basis of the unambiguously word-level behaviour of nasal-initial suffixes, we can conclude that SCF applies at the stem level in English.

Turning now to syncope, those vowel-initial word-level suffixes are relevant here that can be added to stems ending in a schwa + sonorant sequence. From these, -able, -ing, -er, and -ary/-ery/-ory mostly trigger syncope in the preceding syllable, providing evidence for the word-level status of this process (and the last suffix is especially interesting because here the first vowel of the suffix typically also alternates with zero, sometimes giving syncope two options to apply within the same word), see (29a). On the left in (29), examples are shown where syncope is possible, whereas in examples on the right only SCF can apply.

(29) Syncope: Vowel-initial word-level suffixes

(a) measurable ['mєzrəbl] questionable ['kwєstynəbl]

$\begin{array}{llll}\text { blithering } & \text { ['blıðrin] } & \text { wuthering } & \text { ['wıðriry] } \\ \text { traveler } & \text { ['trævlə] } & \text { wagoner } & \text { ['wægñ }] \\ \text { missionary } & \text { ['mIJnri] } & \text { pupilary } & \text { ['pju:plri] } \\ & \text { ['mIJnri] } & & \end{array}$



(b) impressionist [Im'prefnist] novelist ['novlist] devilish ['devlif] kittenish ['kitnif]
(c)



The suffixes -ist, -ish and -age, on the other hand, more often occur with a syllabic consonant than with complete syncope, see (29b). Frequency clearly plays a role in this difference. Finally, -ism and -ise, bearing secondary stress, never allow for syncope, see (29c), and in about half of the cases not even for SCF (e.g. mechanism, monopolise).

Thus, we have seen that SCF applies at the stem level, while syncope applies at the word level in English (contrary to Borowsky's 1993 analysis). ${ }^{26}$ The stemlevel status of SCF supports Coetzee \& Pater's (2011) claim that variable and non-categorical processes are not restricted to the late phonology.

Let us start the analysis with syllabic consonant formation, at the stem level. The ranking of the relevant constraints is given in (30a).

(30) Syllabic consonant formation: Constraints

(a) $|\mathrm{C}|<|\mathrm{V}|$, *SYLOBS »*ว »*SyLSON, FAITH(ə)

(b) $|\mathrm{C}|<|\mathrm{V}|$

A segment connected to a $\mathrm{C}$ position is less sonorous than the segment connected to the following $\mathrm{V}$ position.

(c) $\operatorname{Faith}(\partial)$

A [ə] in the input corresponds to a [ə] in the output.

*SylOBs, *SylSon, and *əa are markedness constraints militating against syllabic obstruents, syllabic sonorants, and schwa, respectively. $|\mathrm{C}|<|\mathrm{V}|$ and FAITH(ə) are formulated rather informally, as a detailed discussion of melodic representations in Government Phonology is beyond the scope of this paper.

The input representations to SCF are given in (31a), while the (potential) outputs with a syllabic consonant appear in (31b), for the examples memory, apathy and colony.

[26] Borowsky (1993) claims that SCF belongs to the word level, whereas syncope is postlexical. Both of these claims are problematic, however. In her formulation, SCF only applies to domain-final sonorants, and therefore initial consonants of word-level suffixes, as in (27)(28), are not expected to undergo it. But this formulation also excludes syllabic consonants from stem-level derivatives (like poisonous ['pəIzənəs]/['pərznəs]/['pэrznəs]) and from monomorphemic forms (like memory or faculty, discussed above), which is incorrect. In addition, if syncope is postlexical, we expect it to apply across-the-board, without exhibiting the lexical variation found. 
(a) Schwa



(b) Syllabic consonant

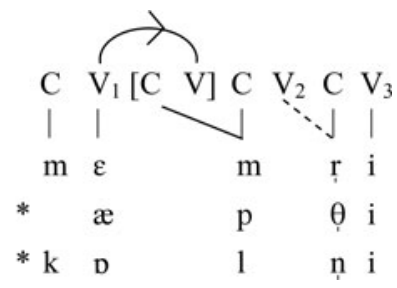

As noted above, in Stratal OT, lexical entries are fully prosodified stem-level output structures (Bermúdez-Otero 2012), already containing the results of processes applying in lexical redundancy mode (such as stress, and the extra CV unit constituting the virtual geminate). SCF, a variable process, applies in standard mode, therefore its result is not included in the lexical representation.

The combined tableau in (32) shows how the ranking in (30a) derives SCF in English. In the tableaux, virtual geminates are indicated by doubling of the symbol.

Syllabic consonant formation

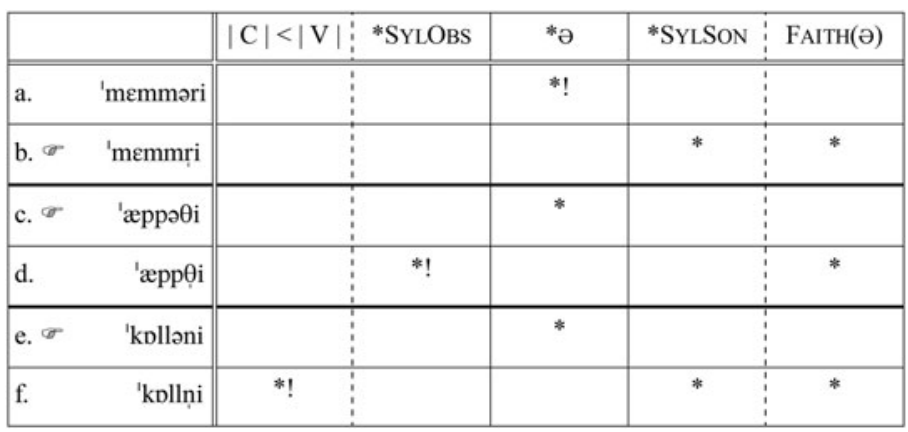

The candidate with a schwa is identical to the input in each case, shown in (31a). For memory, that candidate (32a) loses by violating * ${ }^{2}$. Candidate $(32 b)$ with a syllabic consonant wins, demonstrating the ranking: *ə »*SYLSon, Faith(ə). That is, it is better to have a syllabic sonorant in an unstressed position than a schwa. In apathy, in (32c-d), in contrast, it is not possible to eliminate the schwa because the following consonant is an obstruent, which cannot become syllabic in English, establishing the ranking: *SYLOBS $» *$. Finally, in colony, in $(32 \mathrm{e}-\mathrm{f})$, although the following consonant is a sonorant, it is less sonorous than the preceding one, and again SCF is impossible, providing evidence for the ranking: $|\mathrm{C}|<|\mathrm{V}| » *_{\partial}{ }^{27}$

[27] As *ə is ranked above FAITH(ว), a more specific faithfulness constraint protecting schwa word-finally needs to be ranked above $*_{\partial}$ to prevent deletion or modification in this position. 
Finally, SCF is optional in English, which can be expressed in different ways. Among the models discussed by Anttila (2007), both Multiple Grammars Theory, with competing total rankings, and the theory of Partially Ordered Grammars, with a total ranking randomly selected at each evaluation, can account for this variation. Here I opt for the theory of Partially Ordered Grammars. The relevant ranking is the one between *ə and *SYLSON. When the ranking *SYLSON »* $*_{\partial}$ is selected, the evaluation of apathy and colony remains intact, but memory also surfaces with a schwa instead of a syllabic consonant. As a result, the ranking of these two constraints is unspecified at the stem level in English, accounting for the free variation between the schwa and the syllabic consonant.

Let us now turn to the account of syncope, at the word level. The relevant constraints can be (informally) formulated as in (33).

(33) Syncope: Constraints

(a) StressPG

A stressed position must properly govern an empty nucleus to its right.

(b) *VIRTGEM

Virtual geminates are prohibited.

(c) NoLApse

No sequences of unstressed vowels.

(d) $\operatorname{FAith}(\mathrm{SyL})$

A consonant connected to a $\mathrm{V}$ position in the input is also connected to that $\mathrm{V}$ position in the output.

(e) $\operatorname{FAITH}(\mathrm{CV})$

A CV unit present in the input is also present in the output.

(f) $*|\mathrm{C}|<|\mathrm{C}| \#$

In word-final consonant clusters, sonority cannot rise.

STRESSPG expresses the requirement introduced in Section 3 above in an OT-style constraint. The constraint *VIRTGEM indicates the markedness of such configurations. Perhaps it should simply prohibit geminates, as that is what these consonants are phonologically, and their virtuality is just a matter of phonetic interpretation. But for the sake of clearer exposition, I keep the present formulation. NoLAPSE rules out sequences of unstressed pronounced $\mathrm{V}$ positions, whether these are filled by vocalic or consonantal melody (see Hammond $1997 \mathrm{~b}$ for a similar formulation of the triggering force behind syncope as aiming at improvement in footing). I use FAITH(CV) instead of MAX because inside a domain Cs and Vs cannot be deleted separately. Also, this constraint only refers to

In addition, SCF needs to be blocked in pre-tonic position by another higher-ranked constraint. I discuss the latter restriction further below. 
skeletal units, and it is oblivious to melody. ${ }^{*}|\mathrm{C}|<|\mathrm{C}| \#$ only specifies that sonority cannot rise within a word-final consonant cluster, but the solution of realising the intervening $\mathrm{V}$ position will be decided by lower-ranked constraints (against epenthesising vocalic melody or spreading consonantal melody).

The representations of the relevant candidates are illustrated in (34), through the example of ráti(o)nal ['ræ[nl]. The structure in (34a) gives the input ['ræfnl], with the syllabic consonants already present, having been created at the stem level, and containing a lapse of unstressed $V_{2}$ and $V_{3}$.

Syncope: Candidates

(a) Lapse

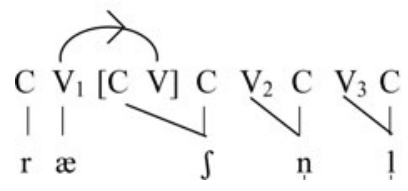

(c) Syncope of $\mathrm{V}_{3}$

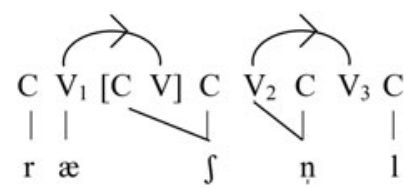

(b) Syncope of $\mathrm{V}_{2}$

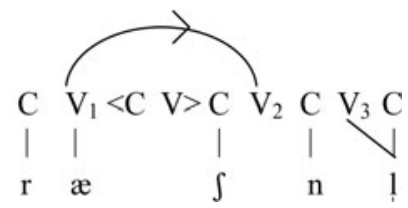

(d) No virtual geminate



In (34b), syncope of $\mathrm{V}_{2}$ is shown, ['ræjnl], whereby the lapse is avoided. To be able to properly govern $\mathrm{V}_{2}, \mathrm{~V}_{1}$ can no longer govern the $\mathrm{V}$ position of the extra $\mathrm{CV}$ unit, which is therefore removed from the representation (shown by angle brackets), and the geminate shortens. This is parallel to the mechanism of closed syllable shortening, proposed by Rowicka (1999a). Note that to be able to do this, the Projection Principle needs to be modified slightly: the head of the governing relation in (34b) is the same as in (34a), only its target changes. I propose the revision in $(35)$.

Projection Principle (revised)

Governing heads defined at the level of lexical representation remain constant throughout a phonological derivation.

Structure (34c) shows a candidate with syncope of the $\mathrm{V}_{3}$ position, *['ræfnl]. Lapse is avoided, the virtual geminate is preserved, but a rising sonority cluster is created at the end of the word. Finally, in (34d), a candidate without either syncope or a virtual geminate is provided, *['ræ[n!l], where, however, the stressed position fails to properly govern an empty nucleus to its right, and therefore the Stress-to-Weight requirement is violated.

The tableau for this example is provided in (36). 


\begin{tabular}{|c|c|c|c|c|c|c|c|}
\hline 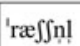 & & STRESSPG & ${ }^{*}|\mathrm{C}|<|\mathrm{C}| \#$ & NOLAPSE & FAITH(SYL) & *VIRTGEM & FAITH(CV) \\
\hline a. & 'ræ $\iint \underline{n !}$ & & & *! & & $*$ & \\
\hline b. $\sigma$ & 'ræfnl & & & & $*$ & & $*$ \\
\hline c. & 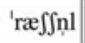 & & $* !$ & & $*$ & $*$ & \\
\hline d. & 'ræenl & $* !$ & & * & & & * \\
\hline
\end{tabular}

The input contains a sequence of syllabic consonants and a virtual geminate. If it is unchanged, as in (36a), a violation of NoLAPSE occurs, and *VIRTGEM is also violated. Candidate (36b), exhibiting syncope of the first syllabic consonant, $\mathrm{V}_{2}$, satisfies both of these constraints, violating the two faithfulness constraints, which must thus both be ranked below NoLAPSE. Candidate (36c), where it is the second syllabic consonant which is left 'desyllabified', violates *VIRTGEM instead of FAITH(CV) (whose (lack of) ranking I will return to below), but it loses because of its word-final rising sonority cluster. The rankings of FAITH(SYL) above *VIRTGEM, and of * $\mathrm{C}|<| \mathrm{C} \mid \#$ above NoLAPSE can only be demonstrated on the basis of later examples. Finally, (36d) shows that the violation of *VIRTGeM can only be avoided without syncope by disobeying StREssPG, which is fatal because this constraint is top-ranked as it can never be violated in English.

Syncope, similarly to SCF, is optional in English. This can be expressed by leaving the ranking between NoLAPSE and FAITH(SYL) unspecified. The ranking in (36) is then one of the options taken at each actual evaluation. The other option is shown in (37), with the output ['ræenl] in this case.

Lack of syncope

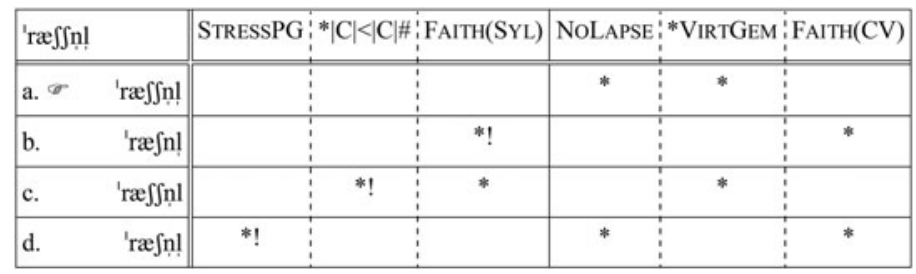

Changing this ranking does not affect the fate of candidates (c) and (d), but candidate (a) is now more harmonic than candidate (b), and by virtue of that it wins. Comparing candidates (a) and (d), this tableau also demonstrates the ranking of StressPG above *VIRTGem, resulting in the existence of virtual geminates, also at the word level. ${ }^{28}$ From now on I will only illustrate the ranking causing syncope,

[28] This ranking will become more obvious after observing the next tableau, where it is shown that the ranking between *VIRTGem and Faith $(\mathrm{CV})$ is decided at each actual evaluation. When *VirtGem is ranked above Faith(CV), it must in turn be dominated by StressPG to ensure the victory of candidate (37a) over (37d). 
NoLAPSE » Fatth(Syl), with the understanding that this is just one of the possibilities, and the opposite ranking is also available for all of the examples below, resulting in a non-syncopating form.

Let us now examine the behaviour of forms like missi(o)n(a)ry, where in a row of three unstressed syllables the first two contain a syllabic consonant, out of which the second is more sonorous than the first one. In such forms either syllabic

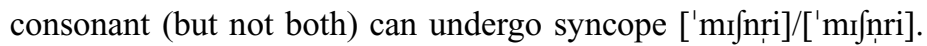

\section{Two options for syncope}

\begin{tabular}{|c|c|c|c|c|c|c|}
\hline 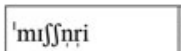 & STRESSPG & : ${ }^{*} \mathrm{C}|<| \mathrm{C} \mid \#$ & NoLAPSE & FAITH(SYL) & *VIRTGEM &  \\
\hline 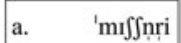 & & & $* * !$ & & $*$ & \\
\hline b. $\sigma \quad$ 'mIfnrị & & & * & $*$ & & * \\
\hline c. $\sigma \quad$ 'mI $\iint n$ ri & & & * & * & $*$ & \\
\hline
\end{tabular}

Comparing (38b), where the first syllabic consonant desyllabifies, with (38c), where the second one does, we find that they tie on NoLApSE and Faith(SYL), and the only difference between them is that (38b) incurs a violation of FAITH(CV), while (38c) incurs a violation of *VIRTGEM. ${ }^{29}$ As both forms are possible outputs, this provides evidence for leaving the ranking between the latter two constraints unspecified. At each actual evaluation the ranking will be established in favour of one of the constraints, accounting for the free variation found in such examples. As the choice is based on the presence or absence of virtual geminates, this variation provides independent support for the analysis of stressed vowels proposed in this paper.

So far NoLAPSE has been treated as a categorical constraint. The example in (38) above shows that this cannot work because the actual outputs still contain a lapse, and syncope in these cases would not improve the situation in this respect. However, syncope does occur, and therefore we must conclude that NOLAPSE is a gradient constraint, violated once when there is a sequence of two unstressed vowels, and every further unstressed vowel adds an extra violation. This is how the candidate in (38a) is ruled out. Note also that it is not possible to avoid the lapse completely by desyllabifying both syllabic consonants because properties of proper government and the Empty Category Principle rule out creation of sequences of empty nuclei, and such candidates are therefore not even provided by Gen.

[29] The representation of (38c) corresponds to that given in (34c), with an additional V position at the end. This form contains an extra governing relation compared to the input (34a). Note that this does not contradict the Projection Principle as revised in (35), whereby only removal of governing heads is prohibited. In fact, to account for word-level syncope, addition of governing relations becomes necessary also if one utilises iambic proper government. 
Observe also that all the examples allowing for such double options for syncope contain the suffix -ory/-ary/-ery. This is so because all the other word-level suffixes that typically allow for syncope, -able, -ing and -er, attach to verbs, and there are no verbs ending in a sequence of syllabic consonants in English (antepenultimate stress being atypical for verbs in general). The only other forms containing the relevant sequences are derived by the suffix -ly, as in traditi(o)nally [tro'difnli], but these examples never desyllabify the second syllabic consonant. In fact, the behaviour of -ly is rather peculiar: apart from the suffix combinations -ic-(a)l-ly, where syncope is always possible, and $-f(u) l-l y$, where syncope can occur in about half of the cases, in almost all other examples syncope is not permitted before -ly, even when a stressed syllable directly precedes (e.g. háppily ['hæpli]/*['hæpli]). At present I cannot account for the behaviour of this suffix.

Tableau (39) shows the case when a syllabic consonant is followed by a stressed vowel, as in flànnelétte [,flænl'et]. We have seen above that SCF is not always possible before a stressed vowel, but even when it is, such syllabic consonants never proceed further to syncope.

\section{Lack of pre-tonic syncope}

\begin{tabular}{|c|c|c|c|c|c|c|}
\hline ,flænnl'ett & STRESSPG & $*|\mathrm{C}|<|\mathrm{C}| \#$ & NOLAPSE & FAITH(SYL) & "VIRTGEM & :FAITH(CV) \\
\hline a. $\sigma_{,}$flænn!' $\varepsilon t t$ & & & & & $* *$ & \\
\hline b. flænl'ett & & & & $* !$ & * & * \\
\hline
\end{tabular}

The reason is that there is no triggering force, as there is no metrical lapse in forms like this. NoLAPSE being satisfied, a violation of FAITH(SYL) proves fatal in this case, see (39b). Therefore syncope does not occur, and the virtual geminate is preserved, see (39a). Hence, this tableau demonstrates the ranking of FAITH(SyL) »*VIRTGEM.

Forms like háppen ['hæpn] (represented in (24b) above) exhibit lack of syncope partly for the same reason, as shown in (40).

Lack of syncope in a word-final syllable

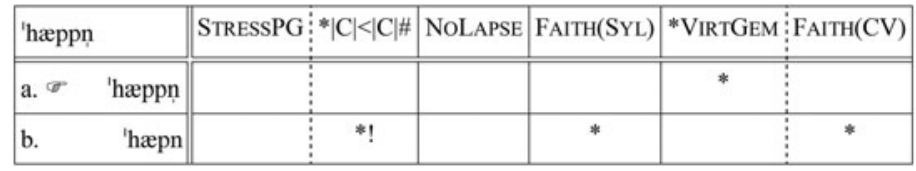

If there is no triggering lapse, maintaining a syllabic consonant is more important than avoiding a virtual geminate. In fact, there is also another reason: syncope in this case would create a rising sonority cluster at the end of the word, violating the constraint * $\mathrm{C}|<| \mathrm{C} \mid \#$.

Now let us see why syncope is not possible when there is no syllabic consonant in a word. In a form like colony ['kpləni], there is a lapse that cannot be repaired 
because the sonority relations are such that a syllabic consonant cannot be formed either, see (41).

Lack of syncope without SCF

\begin{tabular}{|c|c|c|c|c|c|c|c|}
\hline 'kolləni & & STRESSPG & FAITH(ə) & NOLAPSE & FAITH(SYL) & *VIRTGEM & $\begin{array}{lll}\text { FAITH(CV) }\end{array}$ \\
\hline a. $\sigma$ & 'kolləni & & & $*$ & & * & \\
\hline b. & 'kolni & & $* !$ & & & & * \\
\hline c. & 'kpləni & *! & & * & & & * \\
\hline
\end{tabular}

The candidate in (41b), with syncopation of the schwa, fails, which provides evidence for ranking FAITH(ə) above NoLAPSE. Candidate (41a) wins over (41c) because it satisfies StressPG by containing a virtual geminate. This tableau thus also demonstrates the ranking of STRESSPG »*VIRTGEM.

But what happens if the first unstressed syllable contains a schwa and the second a syllabic consonant, as in terrible ['terəbl] in (42)?

Lack of syncope without SCF or of a word-final syllabic consonant

\begin{tabular}{|c|c|c|c|c|c|c|c|}
\hline 'terrabl & & ${ }^{*}|\mathrm{C}|<|\mathrm{C}| \#$ & FAITH(ə) & NOLAPSE & FAITH(SYL) & *VIRTGEM & FAITH(CV) \\
\hline a. $\sigma$ & 'terrabl & & & $*$ & & * & \\
\hline b. & 'terbl & & $* !$ & & & & * \\
\hline c. & 'terrabl & $*$ ! & & & $*$ & $*$ & \\
\hline
\end{tabular}

Syncopation of the schwa in (42b) is ruled out in the same way as it was in (41b). Syncopation of the syllabic consonant is not possible either, however, as that would create a word-final rising sonority cluster, as in (42c) (similarly to ['ræjnl] in (36c) and ['hæpn] in (40b)), proving the ranking of $*|\mathrm{C}|<|\mathrm{C}| \#$ above NoLAPSE.

When the syllabic consonant in such a configuration is not word-final but is followed by a vowel, as in monit(o)ring ['monətrin] in (43), syncopation becomes available.

Syncope of a non-word-final syllabic consonant

\begin{tabular}{|c|c|c|c|c|c|}
\hline 'monnatrin & $\left.{ }^{*}|\mathrm{C}|<|\mathrm{C}| \#\right)$ FAITH(ə) & NOLAPSE & FAITH(SYL) & *VIRTGEM & FAITH(CV) \\
\hline a. 'monnotrim & 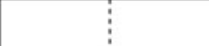 & $* * !$ & & * & \\
\hline b. 'montrim & *! & * & & & $*$ \\
\hline c. $\sigma$ 'monnətrin & 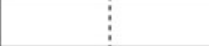 & * & * & * & \\
\hline
\end{tabular}

Again, syncopating the schwa violates higher-ranked FAIтH(ə), see (43b). Here, however, * $\mathrm{C}|<| \mathrm{C} \mid \#$ has no say, as the created rising sonority cluster is not final, and therefore the syllabic consonant can desyllabify in (43c) (similarly to ['mifnri] in (38c) above). 
It is the same ranking that accounts for the existence of forms like innovat(o)ry ['InəvətrI], where the sonority relations are such that they only permit syncope in the suffix, which, however, is two syllables away from the stressed vowel, see (44).

Syncope farther away from the stressed vowel

\begin{tabular}{|c|c|c|c|c|c|c|}
\hline 'Innəvətri & ${ }^{*}|\mathrm{C}|<|\mathrm{C}| \#$ & FAITH(ə) & NoLAPSE & FAITH(SYL) & *VIRTGEM & FAITH(CV) \\
\hline a. 'Innəvətrị & & & $* * * !$ & & * & \\
\hline b. 'Invatri & & $* !$ & ** & & & * \\
\hline c. $\sigma$ 'Innəvatri & & & $* *$ & * & * & \\
\hline
\end{tabular}

This tableau is identical to the previous one, except for an extra NoLAPSE violation for each candidate.

Now that we have seen that syncope is also possible when the syllabic consonant is not immediately post-tonic, the question arises what happens when the vowel following such a syllabic consonant is stressed. The analysis in (43)(44) predicts that syncope should be possible here because a lapse is present to be avoided. Examples containing this configuration are limited and can be divided into two types on the basis of whether the following stress is primary or secondary. Secondary stress is found in forms with the suffixes -ism and -ise, shown in (45a).

(45) Pre-tonic lapse: Preceding secondary stress

(a) hooliganism ['hu:ləgn, $\left.\mathrm{IZm}_{1}\right]$ militarism ['milətə, $\mathrm{rIZm}_{1}$ personalise ['pз:snl, arz] categorise ['kætəgə, raiz]

(b) Catalan ['kætlın] shibboleth ['jibə,l $1 \varepsilon \theta]$ ['Jibləo]

As can be seen, syncope is not possible in these cases, and even SCF is restricted. Examples on the left can exhibit SCF, while examples on the right cannot. Examining the two types of examples containing the suffix -ism, the following generalisation arises: SCF is not possible when the suffix is attached to a bound base, as in militarism, whereas with a free base, as in hooliganism, SCF is usually allowed (although there are some exceptions, like secularism). This is in harmony with the fact that SCF is normally ruled out before a stressed vowel in monomorphemic forms, too, as in shibbolèth in (45b), where SCF is only possible when the final vowel is reduced. There are only a handful of examples like Cátalàn, with a possible syllabic consonant. In forms containing the suffix -ise, the correspondence between bound bases and lack of SCF is less perfect, but it is still present as a tendency.

I propose to account for the difference between the two types with the help of domains. In Stratal OT (Bermúdez-Otero 2012, following Kaye 1995), stem-level morphology is represented non-analytically, i.e. it is stored as a single unit 
together with the stem, whereas word-level morphology is analytic, i.e. it results from concatenation. In addition, compounding structures also exist, where each member constitutes a well-formed domain on its own, by containing a full vowel, which is not required of affixes of the other two types that thus can be subminimal.

When -ism and -ise attach to bound bases, they form a non-analytic structure, and they must be present at the stem level, where SCF is blocked before them, similarly to a position preceding stressed vowels within monomorphemic forms. When they attach to free bases, on the other hand, they are added analytically at the word level, when SCF had already a chance to apply at the stem level. To explain why syncope is still blocked in these cases, I propose that these suffixes form a separate domain from the stem (e.g. [[hóoligan][ìsm]]), similarly to members of compounds. Syncope then cannot apply because that would create a domain-final rising sonority cluster, similarly to (42). ${ }^{30}$ Accordingly, the constraint in (33f) should refer to domain-final clusters instead of word-final ones. This analysis is supported by the fact that these suffixes contain a full vowel, which bears secondary stress. Hence, the stress pattern of such forms is identical to that of true (or initially stressed) compounds in English (like [[cán][òpener]]). The few words like Cátalàn will also need to be analysed with a compounding structure, although in their case this is not supported by morphological evidence and is therefore quite abstract.

Examples of a pre-tonic lapse where the following stress is primary are provided in (46a).
Pre-tonic lapse: Preceding primary stress
(a) nationalistic [,næ[n!l' Istrk] probabilistic [,probəbə'listrk] terminological [,t3:mənl'bdzıkl] mineralogical [,minrə'lodzıkl]
(c) fatalistic hullabaloo [,h^ləbə'lu:]
(d) Catalina
[,fertl' istrk] impressionistic eucalyptus [Im,prejə'nistrk] [,kætl'i:nə] [,ju:kə'liptəs]

Such examples always involve stress-fixing suffixes like -ic (or self-stressed suffixes like -ette, also found in shorter forms, containing no lapse, like flànelétte, discussed above), which we expect to be non-analytic, i.e. belonging to the stem level. Therefore, no SCF (and therefore no syncope) is predicted for these cases, which is in fact borne out in most of the examples, illustrated

[30] In English, sonorants do not occur in monoconsonantal suffixes, and rising sonority sequences cannot be created via syncope even across a word-level boundary. The only suffix providing a potential source is $-e r /-o r$, which however only contains a pronounced $[\mathrm{r}]$ in a rhotic accent like General American. But even in such accents, syncope is ruled out in this environment: developer * [ d'veləpr]. That is, a rising sonority cluster can only be created, if it is immediately followed by a vowel within the same domain. 
on the right in (46a) with free bases (to make the lack of SCF more emphatic). I have only found four examples allowing a syllabic consonant in this configuration, illustrated on the left, one of them containing a bound base (making the occurrence of SCF even less expected here). The example in (46b) shows that monomorphemic items of the same type never permit SCF to apply. When we examine shorter forms, illustrated in (46c), we also find that most examples behave like imprèssionistic, and resist SCF, although there are about seventy words like fàtalístic, with an optional syllabic consonant (again including some with a bound base). Finally, shorter monomorphemic forms again normally disallow SCF, but there are a handful of exceptions like Càtalina, in (46d). None of these examples exhibit syncope.

For the few words in the left-hand column, I again propose a compound structure analysis (e.g. [[nàtional][ístic]]). Such words resemble finally stressed compounds in English, such as [[wèek][énd]]. SCF may apply in them, but syncope may not, because that would create a domain-final rising sonority cluster. Again, for the bound bases and for the monomorphemic examples, this analysis is not independently supported by morphology. Note also that the analysis of flànelétte presented in (39) above now becomes completely parallel to the analysis of háppen in (40) because the second stressed vowel belongs to a separate domain.

The question now is why SCF is blocked pre-tonically in monomorphemic forms. A possible reason is that spreading from a $\mathrm{C}$ position to a preceding $\mathrm{V}$ position is ruled out if it involves crossing a foot boundary (indicated below by parentheses on the CV tier), as in shibboleth in (47a).

Spreading across a foot boundary

(a) Syllabic consonant: ['frbə, $1 \varepsilon \theta$ ]

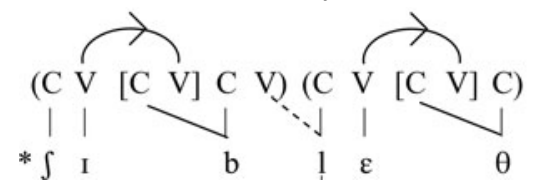

(b) Virtual geminate: [,ræ'ku:n]

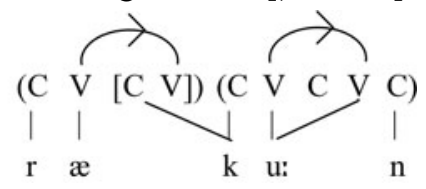

However, spreading from a $\mathrm{C}$ position to a preceding $\mathrm{C}$ position, within a virtual geminate, as in raccoon in (47b), is allowed across such a boundary. A structure like this is thus viable underlyingly, but it cannot be created during the derivation, exemplifying the Emergence of the Unmarked (McCarthy \& Prince 1994). In fact, the generalisation on pre-tonic lack of SCF is a wider one, which also encompasses word-initial pre-tonic sequences, as in career [kə'riə], where SCF is likewise ruled out. This provides extra support for treating pre-tonic and posttonic syncope separately, as only post-tonic syncope goes through a stage of syllabic consonant formation, whereas pre-tonic syncope seems to delete the schwa directly. In fact, there is a further reason for a separate treatment of the two types: pre-tonic lapses are never found word-initially in English, therefore, pre-tonic syncope must have a different trigger. 
In this analysis, syncope in English falls out of the interplay between three forces: the drive behind syncope is lapse avoidance, but its position is determined by the requirement on stressed positions to properly govern, and by the ban on rising sonority clusters in domain-final position. The OT analysis has also prompted the identification of SCF as a stem-level process. In addition, free variation can be naturally expressed in the theory of Partially Ordered Grammars. The lexical variation based on relative usage frequency could be accounted for by, for example, lexically indexed faithfulness constraints (as proposed by Coetzee 2009 for $t / d$-deletion in English), where lexical items are variably affiliated to different lexical classes. The likelihood of association is determined by a probabilistic distribution function, which in turn is controlled by the item's usage frequency. As the OT analysis presented here can form a natural basis of such an extension, this might provide further support for the present approach. Such an extended account, requiring corpus studies, is, however, left for future research.

\section{Summary}

I have shown that a Loose CV analysis, utilising trochaic proper government, can explain the relationship of stress to the distribution of vowels on the one hand and to syncope on the other. Stressed short vowels occur in 'closed syllables' because stressed positions in English must properly govern an empty nucleus. A stressed short vowel in a seemingly open rhyme is therefore followed by a virtual geminate.

Syncope is triggered by a metrical lapse of unstressed vowels, and it can provide another means of satisfying the requirement of proper government, making virtual geminates unnecessary in these cases. It is blocked, however, if it were to create a domain-final rising sonority cluster. As syncope is always preceded by a stage of syllabic consonant formation, the melodic restrictions on the consonants flanking the syncope site are explained. I have provided further evidence for representing syllabic consonants as branching on a neighbouring $\mathrm{V}$ position, and have argued for parametric variation between a left-branching and a rightbranching structure.

To account for the conspiracy resulting in the intricate pattern of syncope found in English, I have proposed a Stratal OT analysis. This has led me to identify $\mathrm{SCF}$, a variable and gradient process, as belonging to the stem level (contrary to Borowsky's 1993 proposal). The optionality of both SCF and syncope, and the free variation shown by forms where either member of a sequence of syllabic consonants may desyllabify, have been represented by utilising the theory of Partially Ordered Grammars. I have proposed a slight modification to the Projection Principle, by restricting its effect to governing heads.

From the established ranking it follows that syncope is also possible in a not immediately post-tonic position, if there is a following vowel within the word. But in fact syncope is ruled out in this configuration if the following vowel is stressed. In monomorphemic forms, SCF is also disallowed in this position, 
but preceding a word-level suffix, SCF may apply. To account for these facts, I have proposed that such suffixes form a compounding structure with the stem, and syncope is then blocked by the ban on domain-final rising sonority clusters.

I have left the question of why syncope can apply after a consonant cluster or a long vowel for future research. A corpus study on the lexical variation exhibited by syncope, based on relative usage frequency, also goes beyond the scope of this paper.

\section{APPENDIX}

Vowel system of Received Pronunciation

\begin{tabular}{|c|c|c|c|c|c|c|c|c|c|c|c|c|c|c|c|c|}
\hline \multirow[b]{3}{*}{ pre-R } & \multicolumn{6}{|c|}{ short } & \multicolumn{10}{|c|}{ long } \\
\hline & I & $\varepsilon$ & $æ$ & $\mathrm{D}$ & $\Lambda$ & u & $0:_{1}$ & $\mathrm{a}_{1}$ & $\left(3:_{1}\right)$ & i: & u: & eI & əU & aI & $\mathrm{au}$ & II \\
\hline & & & & & & & $\partial_{2}$ & $\mathrm{a}_{2}$ & $3: 2$ & Іә & ขอ & عə & $0_{3}$ & аюә & auอ & эә \\
\hline
\end{tabular}

(a) Short lax

[I] pit

[E] pet

[æ] pat

[D] pot

[^] putt

[v] put (b) Long lax

[o: $\left.:_{1}\right]$ paw

[a: 1 spa

([3: $\left.\mathrm{i}_{1}\right]$ colonel) (c) Long lax pre-R

[o: $\left.:_{2}\right]$ port

$\left[a:_{2}\right]$ part

[3: $]$ pert (d) Tense

[i:] bee

[u:] boo

[eI] bay

[วu] bow

[aI] buy

[av] bough

[ग] boy (e) Tense pre-R

[Iว] beer

[Uว] boor

[عə] bear

$\left[\mathrm{j}_{3}\right]$ bore

[аIə] tire

[avə] tower

[วІว] Moir

The above table shows three relevant dimensions: a distinction in terms of length, tenseness-laxness, and whether or not the vowel must be followed by an (underlying) [r]. The tense-lax classification is based on the phonological behaviour of the vowels, as they pattern together for example in Vowel Shift, or in the way they are influenced by a following [r]. Short vowels are always lax, see (a), and they do not need to be followed by [r]. They cAN be followed by [r], however, if the [r] itself is not separated from a following vowel by a word(-level) boundary, as in carrot [æ] or occurr +ence [ $\Lambda$ ]. Tense vowels are always long, as shown in (d)-(e), realised as monophthongs or diphthongs. In pre-R position, they are obligatorily broken to a centring diphthong or triphthong (or the monophthong 
$\left[\mathrm{j}_{3}\right]$ ), see (e), where the $[\mathrm{r}]$ itself is only realised if it is followed by a vowel. Long lax vowels either result from pre-R broadening, as in (c) (typically accompanied by loss of the triggering [r] - unless the [r] is followed by a vowel across a word (-level) boundary, as in occurr\#ing or occur \# in $\left[3 i_{2}\right]$, in which case we find both broadening and the presence of [r]), or else they are underlying, as in (b). The example of colonel appears in parentheses because it is the sole example containing underlying $\left[{ }^{3} \mathbf{i}_{1}\right]$. Subscript numbers are added to distinguish vowels which sound the same in RP but behave differently. In fact, the three [0:]s are kept distinct by some speakers of General American, as [pv:], [port], and [bor], respectively. Similarly, some of the $\left[a_{1}\right]$ s are pronounced as [æ] in General American, as in bath.

\section{REFERENCES}

Algeo, John. 1974. Syncope in English. South Atlantic Bulletin 39.4, 22-30.

Anttila, Arto. 2007. Variation and optionality. In Paul de Lacy (ed.), The Cambridge handbook of phonology, 519-536. Cambridge: Cambridge University Press.

Balogné Bérces, Katalin. 2011. Syncope in English: Fact or fiction? In Katalin Balogné Bérces, Kinga Földváry \& Rita Mészárosné Kóris (eds.), HUSSE10-Linx [Linguistics volume of HUSSE10 conference proceedings], 27-38. Debrecen: Hungarian Society for the Study of English.

Barillot, Xavier \& Philippe Ségéral. 2005. On phonological processes in the "3rd conjugation" of Somali. Folia Orientalia 41, 115-131.

Bell, Alan. 1978. Syllabic consonants. In Joseph H. Greenberg (ed.), Universals of human language, vol. 2: Phonology, 153-201. Stanford, CA: Stanford University Press.

Bermúdez-Otero, Ricardo. 2012. The architecture of grammar and the division of labour in exponence. In Jochen Trommer (ed.), The morphology and phonology of exponence (Oxford Studies in Theoretical Linguistics 41), 8-83. Oxford: Oxford University Press.

Blaho, Sylvia. 2004. Syllabic consonants in Strict CV. MA thesis, Péter Pázmány Catholic University.

Blevins, Juliette. 1995. The syllable in phonological theory. John Goldsmith (ed.), The handbook of phonological theory, 206-244. Oxford: Blackwell.

Borowsky, Toni. 1989. Structure Preservation and the syllable coda in English. Natural Language \& Linguistic Theory 7, 145-166.

Borowsky, Toni. 1993. On the word level. In Sharon Hargus \& Ellen M. Kaisse (eds.), Phonetics and phonology, vol. 4: Studies in lexical phonology, 199-234. San Diego, CA: Academic Press.

Borowsky, Toni, Junko Itô \& Ralf-Armin Mester. 1984. The formal representation of ambisyllabicity: Evidence from Danish. North East Linguistic Society (NELS) 14, 34-48.

Burzio, Luigi. 2007. Phonology and phonetics of English stress and vowel reduction. Language Sciences 29, 154-176.

Charette, Monik. 1991. Conditions on phonological government. Cambridge: Cambridge University Press.

Chierchia, Gennaro. 1986. Length, syllabification and the phonological cycle in Italian. Journal of Italian Linguistics 8, 5-34.

Chomsky, Noam \& Morris Halle. 1968. The sound pattern of English. New York: Harper \& Row.

Clements, George. 1990. The role of the sonority cycle in core syllabification. In John Kingston \& Mary Beckman (eds.), Papers in Laboratory, vol. 1, 283-333. Cambridge: Cambridge University Press.

Cobb, Margaret. 1997. Conditions on nuclear expressions in phonology. Ph.D. dissertation, School of Oriental and African Studies, University of London.

Coetzee, Andries. 2009. Phonological variation and lexical frequency. North East Linguistic Society (NELS) 38.1, 189-202.

Coetzee, Andries \& Joe Pater. 2011. The place of variation in phonological theory. In John Goldsmith, Jason Riggle \& Alan C. L. Yu (eds.), The handbook of phonological theory, 2nd edn., 401-434. Oxford: Wiley-Blackwell. 
Connolly, John H. 1981. On the segmental phonology of a South Welsh accent of English. Journal of the International Phonetic Association 11.2, 51-61.

Dalby, Jonathan Marler. 1986. Phonetic structure of fast speech in American English. Bloomington, IN: Indiana University Linguistics Club.

Davidson, Lisa. 2006. Schwa elision in fast speech: Segmental deletion or gestural overlap? Phonetica $63,79-112$.

Durand, Jacques \& Bernard Laks (eds.). 1996. Current trends in phonology: Models and methods. Paris: CNRS, ESRI, Paris X.

Fidelholtz, James L. 1975. Word frequency and vowel reduction in English. Chicago Linguistic Society (CLS) 11, 200-213.

Gibb, Lorna. 1992. Domains in phonology: With evidence from Icelandic, Finnish and Kikuyu. Ph.D. dissertation, University of Edinburgh.

Gimson, A. C. 1980. An introduction to the pronunciation of English, 3rd edn. London: Edward Arnold. Guile, Timothy. 1972. A generalization about epenthesis and syncope. Chicago Linguistic Society (CLS) 8, 463-469.

Gussmann, Edmund \& Jonathan Kaye. 1993. Polish notes from a Dubrovnik Cafe: I. The yers. SOAS Working Papers in Linguistics and Phonetics 3, 427-462.

Hall, T. A. 2001. The distribution of superheavy syllables in Modern English. Folia Linguistica 35, $399-442$.

Hammond, Michael. 1997a. Vowel quantity and syllabification in English. Language 73.1, 1-17.

Hammond, Michael. 1997b. Optimality Theory and prosody. In Diana Archangeli \& D. Terence Langendoen (eds.), Optimality Theory: An overview, 33-58. Oxford: Blackwell.

Hammond, Michael. 1999. The phonology of English: A prosodic Optimality-Theoretic approach. Oxford: Oxford University Press.

Hammond, Michael \& Emmanuel Dupoux. 1996. Psychophonology. In Durand \& Laks (eds.), 281-304.

Harris, John. 1994. English sound structure. Oxford: Blackwell.

Harris, John. 2011. Deletion. In Marc van Oostendorp, Colin J. Ewen, Elizabeth Hume \& Keren Rice (eds.), The Blackwell companion to phonology, vol. 3, 1597-1621. Oxford: Wiley-Blackwell.

Hooper, Joan B. 1976. Word frequency in lexical diffusion and the source of morphophonological change. In William M. Christie (ed.), Current progress in historical linguistics, 95-105. Amsterdam: North-Holland.

Hooper, Joan B. 1978. Constraints on schwa-deletion in American English. In Jacek Fisiak (ed.), Recent developments in historical phonology, 183-207. The Hague: Mouton.

Hornby, Albert Sydney, Anthony Paul Cowie \& Jack Windsor Lewis. 1974. Oxford advanced learner's dictionary of current English, 3rd edn. Oxford: Oxford University Press.

Jones, Daniel. 1966. The pronunciation of English, 4th edn. Cambridge: Cambridge University Press.

Kager, René \& Wim Zonneveld. 1986. Schwa, syllables, and extrametricality in Dutch. The Linguistic Review 5, 197-221.

Kaye, Jonathan. 1990. Government in phonology: The case of Moroccan Arabic. The Linguistic Review 6, 131-159.

Kaye, Jonathan. 1995. Derivations and interfaces. In Jacques Durand \& Francis Katamba (eds.), Frontiers in phonology: Atoms, structures, derivations, 289-332. London: Longman.

Kaye, Jonathan, Jean Lowenstamm \& Jean-Roger Vergnaud. 1990. Constituent structure and government in phonology. Phonology 7, 193-231.

Kiparsky, Paul. 2000. Opacity and cyclicity. The Linguistic Review 17, 351-365.

Kreidler, Charles W. 1989. The pronunciation of English: A course book in phonology. Oxford: Basil Blackwell.

Larsen, Uffe Bergeton. 1994. Some aspects of vowel length and stød in Modern Danish. MA thesis, Université Paris 7.

Larsen, Uffe Bergeton. 1998. Vowel length, Raddoppiamento Sintattico and the selection of the definite article in Modern Italian. In Patrick Sauzet (ed.), Langues et grammaire II-III: Phonologie, 87-102. Paris: Université Paris 8.

Lindsey, Geoff \& Péter Szigetvári. 2013. Current British English searchable transcriptions. http:// seas3.elte.hu/cube.

Lowenstamm, Jean. 1991. Vocalic length and centralization in two branches of Semitic (Ethiopic and Arabic). In Alan S. Kaye (ed.), Semitic studies. In honor of Wolf Leslau: On the occasion of his eighty-fifth birthday, 949-965. Wiesbaden: Harrasowitz.

Lowenstamm, Jean. 1996. CV as the only syllable type. In Durand \& Laks (eds.), 419-441. 
Lowenstamm, Jean. 1999. The beginning of the word. In Rennison \& Kühnhammer (eds.), 153-166. McCarthy, John J. \& Alan S. Prince. 1994. The emergence of the unmarked: Optimality in prosodic morphology. North East Linguistics Society (NELS) 24, 333-379.

McCarthy, John J. \& Alan S. Prince. 1995. Faithfulness and reduplicative identity. In Jill N. Beckman, Suzanne Urbanczyk \& Laura Walsh Dickey (eds.), Papers in Optimality Theory (University of Massachusetts Occasional Papers in Linguistics 18), 249-384. Amherst: GLSA.

Nádasdy, Ádám. 2006. Background to English pronunciation. Budapest: Nemzeti Tankönyvkiadó.

Nikiema, Emmanuel. 1989. Vocalic epenthesis reanalyzed: The case of Tangale. In John P. Hutchison \& Victor Manfredi (eds.), Current approaches to African linguistics, vol. 7, 41-51. Dordrecht: Foris.

Patterson, David, Paul C. LoCasto \& Cynthia M. Connine. 2003. Corpora analyses of frequency of schwa deletion in conversational American English. Phonetica 60, 45-69.

Polgárdi, Krisztina. 1998. Vowel harmony: An account in terms of Government and Optimality. The Hague: Holland Academic Graphics.

Polgárdi, Krisztina. 2002. Hungarian superheavy syllables and the Strict CV approach. In István Kenesei \& Péter Siptár (eds.), Approaches to Hungarian, vol. 8: Papers from the Budapest Conference, 263-282. Budapest: Akadémiai Kiadó.

Polgárdi, Krisztina. 2008. The representation of lax vowels in Dutch: A Loose CV approach. Lingua $118-119,1375-1392$.

Polgárdi, Krisztina. 2012. The distribution of vowels in English and trochaic proper government. In Bert Botma \& Roland Noske (eds.), Phonological explorations: Empirical, theoretical and diachronic issues (Linguistische Arbeiten 548), 111-134. Berlin \& New York: Mouton de Gruyter.

Price, P. J. 1980. Sonority and syllabicity: Acoustic correlates of perception. Phonetica 37, 327-343.

Prince, Alan S. \& Paul Smolensky. 1993. Optimality Theory: Constraint interaction in generative grammar. Ms., Rutgers University \& University of Colorado, Boulder. [Published 2004, Malden, MA \& Oxford: Blackwell.]

Rebrus, Péter. 2000. Morfofonológiai jelenségek [Morphophonological phenomena]. In Ferenc Kiefer (ed.), Strukturális magyar nyelvtan, 3. kötet: Morfológia [A structural Hungarian grammar, vol. 3: Morphology], 763-947. Budapest: Akadémiai Kiadó.

Rennison, John. 1999. Syllables in Western Koromfe. In Harry van der Hulst \& Nancy Ritter (eds.), The syllable: Views and facts, 311-347. Berlin \& New York: Mouton de Gruyter.

Rennison, John \& Klaus Kühnhammer (eds.). 1999. Phonologica 1996: Syllables!? The Hague: Holland Academic Graphics.

Rowicka, Grażyna. 1999a. On trochaic Proper Government. In Rennison \& Kühnhammer (eds.), 273288.

Rowicka, Grażyna. 1999b. On ghost vowels: A Strict CV approach. The Hague: Holland Academic Graphics.

Rubach, Jerzy. 1996. Shortening and ambisyllabicity in English. Phonology 13, 197-237.

Scheer, Tobias 1999. A theory of consonantal interaction. Folia Linguistica 32.3-4, 201-237.

Scheer, Tobias. 2004. A lateral theory of phonology: What is CVCV, and why should it be? Berlin \& New York: Mouton de Gruyter.

Scheer, Tobias. 2009. Syllabic and trapped consonants in the light of branching onsets and licensing scales. In Gerhild Zybatow, Uwe Junghanns, Denisa Lenertová \& Petr Biskup (eds.), Studies in formal Slavic phonology, morphology, syntax, semantics and information structure: Proceedings of FDSL 7, Leipzig 2007 (Linguistik International 21), 411-426. Frankfurt am Main: Peter Lang.

Ségéral, Philippe \& Tobias Scheer. 2001. Abstractness in phonology: The case of virtual geminates. In Katarzyna Dziubalska-Kołaczyk (ed.), Constraints and preferences, 311-337. Berlin \& New York: Mouton de Gruyter.

Ségéral, Philippe \& Tobias Scheer. 2008. The Coda Mirror, stress and positional parameters. In Joaquim Brandão de Carvalho, Tobias Scheer \& Philippe Ségéral (eds.), Lenition and fortition, 483-518. Berlin: Mouton de Gruyter.

Szigetvári, Péter. 1999. VC Phonology: A theory of consonant lenition and phonotactics. Ph.D. dissertation, Eötvös Loránd University \& Hungarian Academy of Sciences.

Szigetvári, Péter. 2002. Syncope in English. The Even Yearbook 5, 139-149.

Szigetvári, Péter. 2007. Branching onsets and syncope in English. Language Sciences 29, 408-425.

Thomas, Alan R. 1984. Welsh English. In Peter Trudgill (ed.), Language in the British Isles, 178-194. Cambridge: Cambridge University Press. 
Toft, Zoë. 2002. The phonetics and phonology of some syllabic consonants in Southern British English. ZAS Papers in Linguistics 28, 111-144.

Törkenczy, Miklós. 1992. Vowel-zero alternations in Hungarian: A government approach. In István Kenesei \& Csaba Pléh (eds.), Approaches to Hungarian, vol. 4: The structure of Hungarian, 157-177. Szeged: JATE.

Van der Hulst, Harry. 1984. Syllable structure and stress in Dutch. Dordrecht: Foris.

Van der Hulst, Harry. 1985. Ambisyllabicity in Dutch. In Hans Bennis \& Frits Beukema (eds.), Linguistics in the Netherlands 1985, 57-66. Dordrecht: Foris.

Wells, J. C. 1982. Accents of English. Cambridge: Cambridge University Press.

Wells, J. C. 1990. Longman pronunciation dictionary [LPD]. Harlow: Longman.

Yoshida, Shohei. 1999. Inter-nuclear relations in Arabic. In Rennison \& Kühnhammer (eds.), 335-354.

Zwicky, Arnold M. 1972. Note on a phonological hierarchy in English. In Robert P. Stockwell \& Ronald K. S. Macaulay (eds.), Linguistic change and generative theory, 275-301. Bloomington, IN \& London: Indiana University Press.

Author's address: Research Institute for Linguistics, Hungarian Academy of Sciences, Benczúr u. 33., 1068 Budapest, Hungary

polgardi.krisztina@nytud.mta.hu 